\title{
A Systematic Revision of the Ostracode Species Described by Ulrich and Bassler and by Malkin from the Chesapeake Group in Maryland and Virginia
}

GEOLOGICALSURVEY PROFESSIONAL PAPER 1128 
A Systematic Revision of the Ostracode Species Described by Ulrich and Bassler and by Malkin from the Chesapeake Group in Maryland and Virginia

By RIGHARD M. FORESTER

GEOLOGICAL SURVEY PROFES I ON A L PAPER 1128

Describes new ostracode genera and species

and systematically updates those species

previously described from the Calvert, Choptank, St. Marys, Eastover, and Yorktown Formations

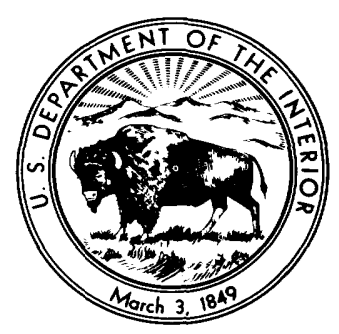




\section{UNITED STATES DEPARTMENT OF THE INTERIOR}

CECIL D. ANDRUS, Secretary

\section{GEOLOGICAL SURVEY}

H. William Menard, Director

\footnotetext{
Library of Congress Cataloging in Publication Data

Forester, Richard M.

A systematic revision of the ostracode species described by Ulrich and Bassler and by Malkin from the Chesa peake Group in Maryland and Virginia.

(Geological Survey Professional Paper 1128)

Bibliography: p. 21

1. Ostracode, Fossil. 2. Paleontology-Tertiary. 3. Paleontology-Maryland. 4. Paleontology-

Virginia. I. Title. II. Series: United States Geological Survey Professional Paper 1128.

QE817.08F67 $565^{\prime} .33 \quad 79-4081$
}

For sale by the Superintendent of Documents, U.S. Government Printing Office

Washington, D.C. 20402

Stock Number 024-001-03179-5 


\section{CONTENTS}

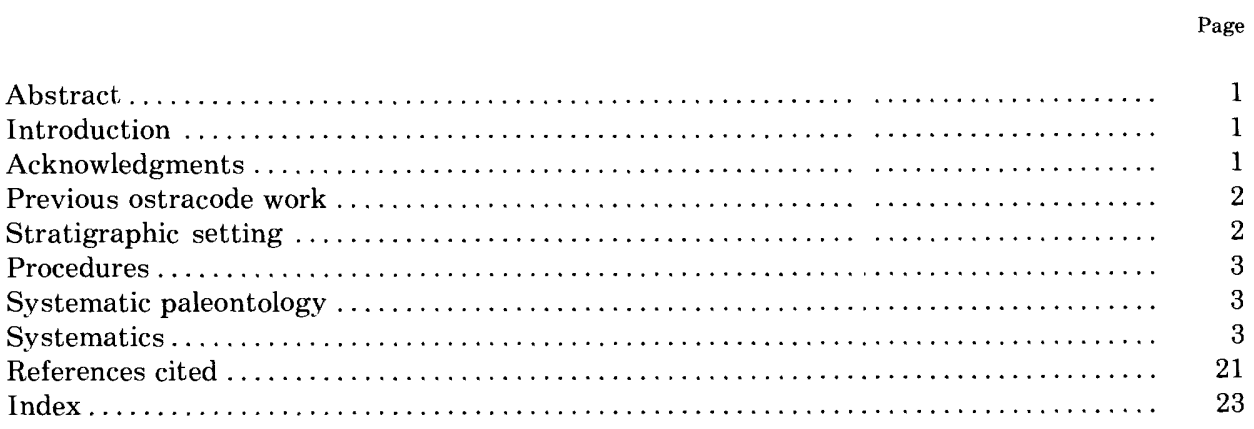

\section{ILLUSTRATIONS}

[Plates follow index]

Plate 1. Cytheridea, Hulingsina, Peratocytheridea.

2. Hulingsina, Cytheropteron?, Cytherura.

3. Murrayina, Actinocythereis.

4. Henryhowella, Actinocythereis, Pterygocythereis, Echino ythereis, Pseudocytheretta.

5. Pseudocytheretta.

6. Otikocythere, Pseudocytheretta, Protocytheretta.

7. Microcytherura, Muellerina, Otikocythere, Bensonocyther ?, Paracytheridea, Thaerocythere.

\section{TABLES}

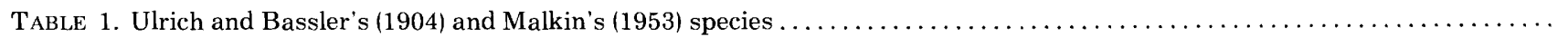

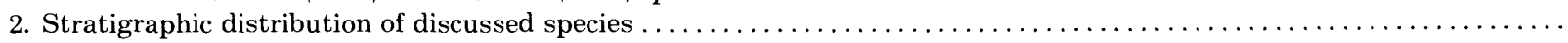




\title{
A SYSTEMATIC REVISION OF THE OSTRACODE SPECIES DESCRIBED BY ULRICH AND BASSLER AND BY MALKIN FROM THE CHESAPEAKE GROUP IN MARYLAND AND VIRGINIA
}

\author{
By RICHARD M. FORESTER
}

\begin{abstract}
Those ostracode species described by Ulrich and Bassler (1904) and Malkin (1953) from the Chesapeake Group of early Miocene to early Pleistocene age are treated systematically. Lectotypes are designated for all species which have syntypic suites and the lectotypes, holotypes, or hypotypes for all but two species are illustrated. A new genus Otikocythere is proposed, with Cythere punctistriata Ulrich and Bassler 1904 as the type species. A new species, Hulingsina calvertensis, is also proposed. All of the species are placed in an updated biostratigraphic framework.
\end{abstract}

\section{INTRODUCTION}

Ulrich and Bassler (1904) and Malkin (1953) described ostracode species from the Chesapeake Group (lower Miocene to lower Pleistocene) of Maryland and Virginia. In ascending order, the Chesapeake Group consists of the Calvert, Choptank, St. Marys, Eastover, Yorktown, and Croatan Formations (Clark and Miller, 1906; Blackwelder and Ward, 1976; Ward and Blackwelder, in press). The Ulrich and Bassler work was particularly important to ostracode systematics because the forms proposed were the first ostracodes described from the North American upper Tertiary. The taxa formed a nucleus for subsequent ostracode systematic and biostratigraphic studies dealing with upper Tertiary, Quaternary, and modern sediments of the Atlantic and Gulf Coasts. The majority of these and, to a lesser extent, the Malkin species, were in need of detailed systematic revision.

In Ulrich and Bassler (1904), many sexual dimorphs and juvenile instars were proposed as distinct species. Conversely, the authors also combined several distinctive (by modern standards) species under a single binomen that are represented by syntypic suites. Both practices, particularly the latter, have led to instability in taxonomic nomenclature because more than one species can be, and often have been, selected as the representatives for a binomen. Furthermore, many subsequent studies have erroneously identified other species as being conspecific with those from the formations of the Chesapeake Group. This has led to a compounding of some of the original problems, thus hampering the utility of these species for systematic and biostratigraphic studies. The seven new species described by Malkin (1953) are also represented by syntypic suites and some of the same problems exist.

The primary purpose of this study has been to examine all of the species described by Ulrich and Bassler (1904) and Malkin (1953) in order to (1) classify them taxonomically, (2) designate lectotypes for all syntypic suites, in keeping with Article 74 of the 1961 International Code of Zoological Nomenclature, and (3) provide adequate illustrations for the lectotypes and holotypes, thereby stabilizing the nomenclature of these ostracode species.

A few of Ulrich and Bassler's (1904) holotypes have been either lost or crushed. Where possible, these species are illustrated herein, using specimens that I feel are consistent with the original authors' concept. Hazel (1977; in press) has already illustrated a few of the Pliocene species in this category and these are not treated in this paper. I have attempted to preserve as many of the original trivial and varietal names as possible. However, this has occasionally meant synonymizing some commonly but erroneously used names. Synonymies are provided and a brief differential diagnosis is given for most species in order to indicate a few of the morphologic features I regard as particularly characteristic.

\section{ACKNOWLEDGMENTS}

This study represents part of a research topic completed while the author was a National Research Council Postdoctoral Associate with the U.S. Geological Survey. I would especially like to thank Joseph E. Hazel who proposed this study and generously provided space and equipment. I would also like to thank 
M. J. Mann and W. Brown of the U.S. National Museum for taking the scanning electron micrographs.

\section{PREVIOUS OSTRACODE WORK}

Howe and others (1935) identified a number of Ulrich and Bassler (1904) species and described several new forms, mostly from Florida correlatives of the Chesapeake Group. McLean $(1957 ; 1966)$ outlined the stratigraphic distribution of some of these ostracode species. Swain (1948) studied ostracodes from the subsurface Chesapeake Group of the Maryland Eastern Shore. Hazel (1967) discussed some of these species in context with a study of the Holocene Hemicytheridae and Trachyleberididae of the North Atlantic, and also dealt with the biostratigraphy and systematics of the ostracodes from the Yorktown Formation (Hazel, $1971 ; 1977$; in press). Swain (1974) treated several ostracode species from the Yorktown and St. Marys Formations. In addition to the study by Howe and others (1935), other important works in which the species of Ulrich and Bassler (1904) have been identified, or thought to have been identified, from other geographic areas are Edwards (1944), Puri (1954) and Swain (1968). In some cases these studies have helped to clarify the taxonomic confusion associated with the Ulrich and Bassler material; however, with the exception of the work by Sandberg (1964) on Peratocytheridea subovata (Ulrich and Bassler, 1904), none of the original material seems to have been studied in any detail.

\section{STRATIGRAPHIC SETTING}

In 1904, Shattuck divided the Calvert, Choptank, and St. Marys Formations into 24 units that he called "zones." The Yorktown Formation, which crops out in nearby Virginia, was not treated by Shattuck; it is, however, normally included in the Chesapeake Group. Shattuck's divisions were based on a variety of criteria (lithology, occurrence or non-occurrence of fossil shells, and others) and, using today's terminology, the divisions are usually not valid lithostratigraphic or biostratigraphic units, but are only beds or groups of beds. His zones 1-15 make up the Calvert Formation, 16-20 the Choptank Formation, and 21-24 the St. Marys Formation. The Calvert Formation was further divided by Shattuck (1904) into the Fairhaven Diatomaceous Earth (zones 1-3) and the Plum Point Marl Members (zones 4-15). Zone 1 crops out at Lyons Creek on the west side of Chesapeake Bay (Deale 71/2-minute quadrangle), and the other zones appear successively as one proceeds south along the bay. Gernant (1970), in a study of the Choptank Formation, concluded that beds 16-20 were distinctive enough to be assigned member status and proposed the names Calvert Beach, Drum Cliff, St. Leonard, Boston Cliffs, and Conoy Members, respectively.

Blackwelder and Ward (1976) have utilized the informal designation of Little Cove Point unit for bed 21 of the St. Marys Formation, because it has a distinctive lithology and fauna. They have also proposed (Ward and Blackwelder, in press) the Eastover Formation to incorporate those sediments that were known as the "Virginia St. Marys." The Eastover Formation includes the Claremont Manor and Cobham Bay Members (also new names), that were once recognized as formations by Blackwelder and Ward (1976).

To facilitate discussion I will refer to the Little Cove Point unit, the St. Marys Formation (as restricted to beds 22-24), and the Claremont Manor and Cobham Bay Members of the Eastover Formation as units A, $B, C$, and D respectively. Work in progress suggests that these units represent important biostratigraphic and lithology units.

Gibson (1971) states that, on the basis of planktic foraminifers, "zone" 10 is referable to planktic zone N8 or N9 of Blow (1969). N8 is considered to be of latest early Miocene age and N9 is earliest middle Miocene (Berggren and Van Couvering, 1974). Well-preserved specimens of the foraminifer Praeorbulina glomerosa circularis (Blow, 1956) have been identified by me (and confirmed by T. G. Gibson, U.S. Geological Survey) from zone 12. This subspecies is indicative of an N9 age for zone 12. The lower Miocene-middle Miocene boundary, therefore, very probably falls in zone 10 or 11 of the Calvert Formation. It is not clear how much of the lower Miocene is represented by the lower Calvert. The similarity of the ostracode and mollusc faunas of the lower zones of the Calvert to zone 10 suggests that only the upper part of the lower Miocene is present. The middle Miocene-late Miocene boundary has been tentatively placed between units $B$ and $C$. This is based on a K/Ar radiometric date of 12.5 m.y. on glauconite from the restricted St. Marys Formation (unit B), coupled with a faunal change in molluses at that level (Blackwelder and Ward, 1976). Berggren and Van Couvering (1974), indicate that radiometrically the middle Miocene-upper Miocene boundary is at about $11.0 \mathrm{~m} . y$. It is possible, however, that the faunally distinct unit $\mathbf{C}$ is also middle Miocene; it contains no diagnostic planktic organisms and no known radiometrically dateable minerals.

Hazel (1977; in press), using various lines of evidence, concluded that the basal beds of the Yorktown Formation are early Pliocene in age (N19 of Blow, 1969) and that the youngest beds legitimately assigned to the Yorktown are probably no younger 
than the N20 zone. Paleontologic and radiometric data summarized by Hazel (1977; in press) and Blackwelder and Ward (1976) suggested that unit D (Cobham Bay Member of Eastover Formation) is of late, but not latest, Miocene age.

Most of the Ulrich and Bassler (1904) ostracode specimens came from "zone" 10 of the Calvert Formation at Plum Point on Chesapeake Bay. Other localities included Church Hill, Md. (Calvert Formation), Peachblossom Creek and Paw Paw Point, Md. (Choptank Formation), and outcrops on the James River in Virginia (Yorktown Formation). Malkin's (1953) material came from zones 4-6, 9, 10, 14, 19, 22 in Maryland and from the Yorktown Formation along the York and James Rivers, Va. The author has examined ostracode material from the above localities (except Church Hill and Paw Paw Point) and from numerous other localities which have ample comparative material. In the strictest sense exact original Ulrich and Bassler localities along Chesapeake Bay no longer exist due to erosion of the cliffs since 1904.

\section{PROCEDURES}

When species from either the Ulrich and Bassler (1904) or the Malkin (1953) collections were represented by syntypes, lectotypes and occasionally paralectotypes have been designated and illustrated for each species. If a species is represented only by a holotype, it has been illustrated if it was extant in the collection (some are not). All illustrations are scanning electron micrographs of gold- or gold-palladium-coated specimens. The known stratigraphic range in the Maryland and Virginia region is given for each species and is based primarily upon studies in progress by Forester on the Miocene part of the Chesapeake Group and by Hazel $(1971 ; 1977$; in press) and Valentine (1971) for the younger deposits. When none of the original specimens exist, or where additional illustrations of non-type material were needed for clarification, samples from U.S. Geological Survey collections have been used. These hypotypes, where possible, were selected from topotype material, recognizing that true topotype material is no longer available, in most cases, due to the erosion of the cliffs along Chesapeake Bay.

All of the illustrated specimens and the remaining Ulrich and Bassler and Malkin specimens are deposited in the collections of the National Museum of Natural History.

\section{SYSTEMATIC PALEONTOLOGY}

The left hand column of table 1 lists in alphabetical order, under their original generic assignments, the species described by Ulrich and Bassler (1904) and Malkin (1953). The right hand column of the table gives my interpretation of the modern generic and species assignment. Each species is discussed in the following section under its updated binomen. Of the original 49 species-group taxa proposed, I feel that only 35 are valid.

The Ulrich and Bassler material has provided the type species for four previously described genera (Henryhowella evax, Murrayina howei, Puriana rugipunctata, and Orionina vaughani). One Ulrich and Bassler species, Cythere punctistriata, is made the type species of the new genus Otikocythere.

Table 2 is a generalized occurrence chart showing the distribution in the Chesapeake Group of the 35 valid taxa. See Hazel (1977) for a more detailed biostratigraphy for the Pliocene. A biostratigraphic treatment of the Miocene forms is in preparation by the author. Occurrence data are given for each species in the following section.

\section{SYSTEMATICS}

Class OSTRACODA Latreille, 1806

Order PODOCOPIDA G. W. Muller, 1894

Suborder PODOCOPA Sars, 1866

Superfamily CYTHERACEA Baird, 1850

Family CYTHERIDEIDAE Sars, 1925

Genus Cytheridea Bosquet, 1852

Type-species.-Cythere mulleri Munster, 1830

Cytheridea diagonalis (Malkin, 1953)

Plate 1, figures 3,6

Clithrocytheridea diagonalis Malkin, 1953, p. 782, pl. 79, figs. 18, $19,21,22,24$

Not Clithrocytheridea diagonalis Malkin. McLean, 1957, p. 74, pl. 8, figs. $1 \mathrm{a}, \mathrm{b}$.

Diagnosis. -Greatest length near the ventral margin and greatest height through central muscle scar region; posterior half of valve drawn out, posteroventral corner extending below ventral margin in females; normal pores (in punctae) irregularly distributed over valve surface; two prominent concentric rows of punctae that form two furrows along anterior margin of valve; larger than Cytheridea virginiensis (Malkin, 1953).

Lectotype. -A female valve (Malkin, 1953, pl. 79; fig. 19), USNM 256018, from the Calvert Formation (locality MD $13-3$ of Malkin, 1953) is herein designated the lectotype (pl. 1, fig. 6).

Measurements. - The lectotype is $900 \mu \mathrm{m}$ (micrometers) in length and $500 \mu \mathrm{m}$ in height. The illustrated 
TABLE 1.-A listing of all of the Ulrich and Bassler (1904) and Malkin (1953) ostracode species by their original designation and by their present (this report) designation

Ulrich and Bassler (1904) or Malkin (1953) taxa

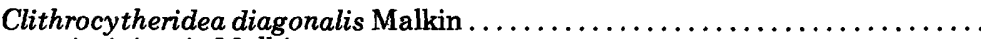
virginiensis Malkin

Cythere burnsi Ulrich and Bassler.

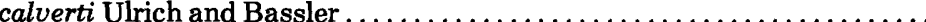

clarkana Ulrich and Bassler.

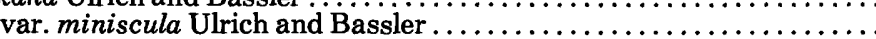

dorsicornis Ulrich and Bassler

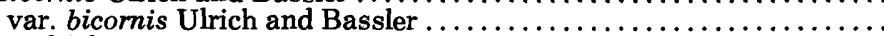
evax Uirich and Bassler...

var. oblongula Ulrich and Bassle...

exanthemata Ulrich and Bassler ........................................

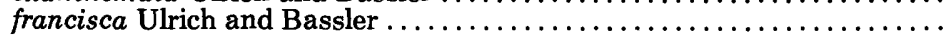

inaequivalvis Ulrich and Bassler...

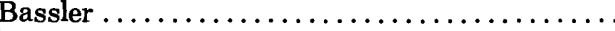

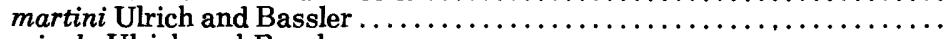

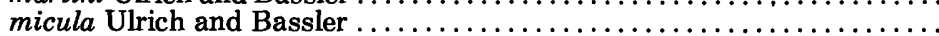

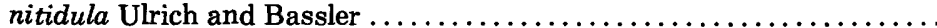

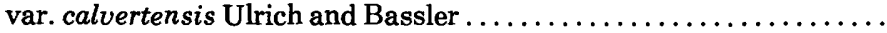

paucipunctata Ulrich and Bassler...

planibasalis Ulrich and Bassler....

plebeia Ulrich and Bassler.

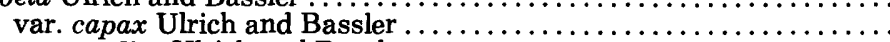

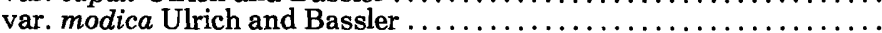

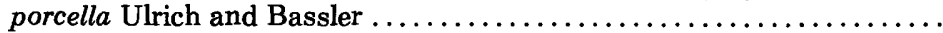

producta Ulrich and Bassler

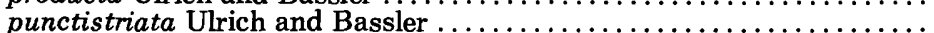

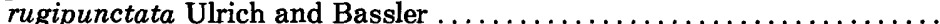

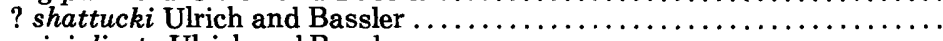

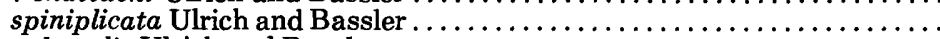

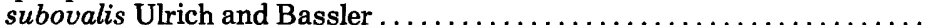

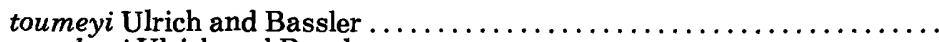
vaughani Ulrich and Bassler.

Cythereis alaris Ulrich and Bassler

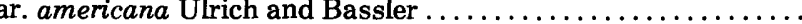

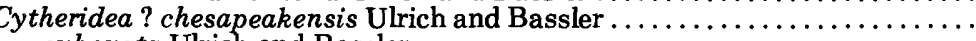

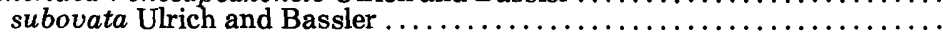

Cytherideis ashermani Ulrich and Bassler.

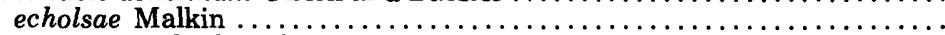

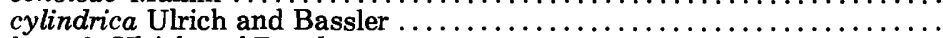
longula Ulrich and Bassler .................................... semicircularis Ulrich and Bassler ..................................

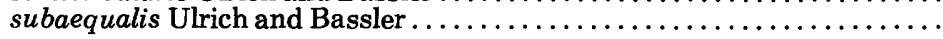

Cytheropteron nodosum Ulrich and Bassler

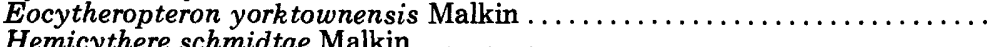

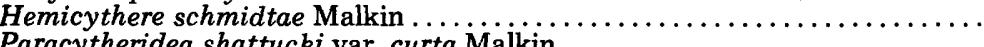

acytheridea shattucki var. curta Malkin ............................

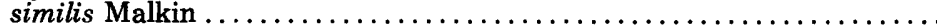

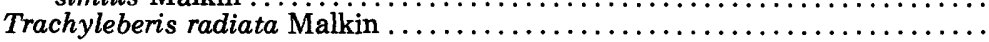

Present assignment

Cytheridea diagonalis (Malkin). virginiensis (Malkin).

Pseudocytheretta burnsi (Ulrich and Bassler).

Bensonocythere calverti (Ulrich and Bassler).

Echinocythereis clarkana (Ulrich and Bassler). miniscula (Ulrich and Bassler).

Murrayina martini (Ulrich and Bassler). howei (Ulrich and Bassler).

Henryhowella evax (Ulrich and Bassler). Do.

Actinocythereis exanthemata (Ulrich and Bassler).

Otikocythere punctistriata (Ulrich and Bassler).

Protocytheretta inaequivalvis (Ulrich and Bassler).

Muellerina lienenklausi (Ulrich and Bassler).

Murrayina martini (Ulrich and Bassler).

Muellerina micula (Ulrich and Bassler).

Pseudocytheretta burnsi (Ulrich and Bassler).

Do.

Do.

Echinocythereis planibasalis Ulrich and Bassler).

Pseudocytheretta plebeia (Ulrich and Bassler).

Do.

Do.

Do.

Murrayina howei (Ulrich and Bassler)

Otikocythere punctistriata (Ulrich and Bassler).

Puriana rugipunctata (Ulrich and Bassler).

Microcytherura shattucki (Ulrich and Bassler).

Henry howella evax (Ulrich and Bassler).

Cytheridea subovalis (Ulrich and Bassler).

Pseudocytheretta burnsi (Ulrich and Bassler).

Orionina vaughani (Ulrich and Bassler).

Actinocythereis sp. (Ulrich and Bassler)

Pterygocythereis americana (Ulrich and Bassler).

$P$ seudocytheretta plebeia (Ulrich and Bassler).

Peratocytheridea subovata (Ulrich and Bassler).

Hulingsina ashermani (Ulrich and Bassler). rugipustulosa (Edwards). cylindrica (Ulrich and Bassler). semicircularis (Ulrich and Bassler).

Do.

subaequalis (Ulrich and Bassler).

Paracytheridea altila (Edwards).

Cytherura coryelli Malkin.

Cytheropteron? yorktownensis (Malkin).

Thaerocythere schmidtae (Malkin).

Microcytherura curta (Malkin). similis (Malkin).

Murrayina radiata (Malkin). paralectotype (pl. 1, fig. 3), USNM 256019 , is $950 \mu \mathrm{m}$ in length and $460 \mu \mathrm{m}$ in height.

Remarks. - Cytheridea diagonalis (Malkin, 1953) exhibits strong sexual dimorphism, with the males being more elongate and lower than the females.

Occurrence.-Malkin (1953) reported this species from the Calvert and Choptank Formations. However, in our collections it occurs throughout the Calvert Formation, but is not present in the Choptank Formation. The specimens reported by Malkin (1953) from the Choptank Formation are all juveniles and their assign- ment to $C$. diagonalis is questionable. As far as is known Cytheridea diagonalis is restricted to the Calvert Formation.

Stratigraphic range.-Lower to middle Miocene.

Cytheridea virginiensis (Malkin, 1953)

Plate 1, figure 7

Haplocytheridea sp. aff. H. israelsky (Stephenson). Swain, 1951, p. 20, pl. 1, figs. 15-17.

Clithrocytheridea virginiensis Malkin, 1953, p. 783, pl. 79, figs. 27, 28; McLean, 1957, p. 74, pl. 8, figs. 2a-g. 
TABLE 2.-Stratigraphic distribution of the Ulrich and Bassler (1904) and Malkin (1953) ostracode species within the Maryland and Virginia Miocene and Pliocene formations

[Leaders (-) indicate not found]

\begin{tabular}{|c|c|c|c|c|c|c|c|}
\hline \multirow[b]{4}{*}{ Taxa } & \multicolumn{6}{|c|}{ Miocene } & 䔅 \\
\hline & \multirow{3}{*}{ 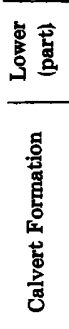 } & \multirow{3}{*}{ 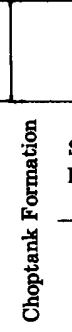 } & \multirow{2}{*}{\multicolumn{2}{|c|}{\begin{tabular}{ll} 
चँच 1 \\
\multirow{2}{*}{1} \\
St. Marys \\
Formation
\end{tabular}}} & \multicolumn{2}{|c|}{ 总产 } & \multirow{3}{*}{ 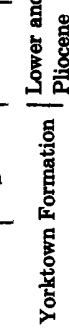 } \\
\hline & & & & & \multicolumn{2}{|c|}{$\begin{array}{c}\text { Eastover } \\
\text { Formation }\end{array}$} & \\
\hline & & & 岂 & $\begin{array}{l}m \\
\stackrel{m}{\mathrm{~g}}\end{array}$ & $\begin{array}{l}0 \\
\text { 苟 } \\
0\end{array}$ & 晃 & \\
\hline 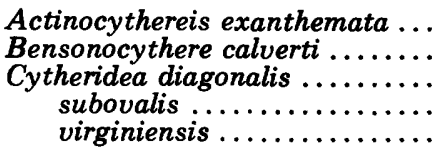 & $\begin{array}{l}x \\
x \\
x \\
x \\
--\end{array}$ & $\begin{array}{l}x \\
-- \\
\ddot{x} \\
--\end{array}$ & $\begin{array}{l}\ddot{.-} \\
\ddot{-} \\
\ddot{.}\end{array}$ & $\begin{array}{l}- \\
- \\
- \\
- \\
-\end{array}$ & $\begin{array}{l}\ddot{x} \\
\ddot{-} \\
\ddot{-}\end{array}$ & $\begin{array}{l}\ddot{\bar{X}} \\
\ddot{-} \\
\ddot{-}\end{array}$ & $\begin{array}{l}\ddot{x} \\
\ddot{x} \\
\ddot{x}\end{array}$ \\
\hline 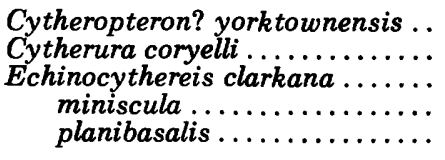 & $\begin{array}{l}\bar{x} \\
\bar{x} \\
x\end{array}$ & $\begin{array}{l}\ddot{x} \\
\ddot{-} \\
\ddot{x}\end{array}$ & $\begin{array}{l}-- \\
-. \\
- \\
-.\end{array}$ & $\begin{array}{l}\ddot{X} \\
-- \\
- \\
--\end{array}$ & $\begin{array}{l}\ddot{-} \\
\ddot{-} \\
\ddot{x}\end{array}$ & $\begin{array}{l}\ddot{-} \\
\ddot{.} \\
\ddot{.} \\
.\end{array}$ & $\begin{array}{l}\mathrm{X} \\
\ddot{-} \\
\ddot{x} \\
\ddot{x}\end{array}$ \\
\hline $\begin{array}{r}\text { Henryhowella evax } \ldots \ldots \ldots \ldots \ldots \\
\quad \text { ashermani } \ldots \ldots \ldots \ldots \ldots \ldots \ldots \\
\quad \text { cylindrica } \ldots \ldots \ldots \ldots \ldots \ldots \\
\quad \text { rugipustulosa } \ldots \ldots \ldots \ldots \ldots \ldots \\
\quad \text { semicircularis } \ldots \ldots \ldots \ldots \ldots \ldots \\
\quad \text { subaequalis } \ldots \ldots \ldots \ldots \ldots\end{array}$ & $\begin{array}{l}x \\
x \\
x \\
x \\
x\end{array}$ & $\begin{array}{l}\ddot{x} \\
x \\
\ddot{x} \\
--\end{array}$ & $\begin{array}{l}\ddot{x} \\
\dot{x} \\
\ddot{x} \\
--\end{array}$ & $\begin{array}{l}\ddot{x} \\
x \\
\ddot{x} \\
--\end{array}$ & $\begin{array}{l}\ddot{x} \\
\ddot{x} \\
x \\
--\end{array}$ & $\begin{array}{l}\ddot{x} \\
\ddot{x} \\
x \\
--\end{array}$ & $\begin{array}{l}-. \\
\ddot{-} \\
\ddot{X} \\
\mathrm{X} \\
--\end{array}$ \\
\hline 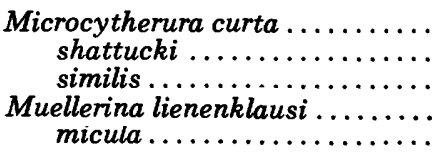 & $\begin{array}{l}-- \\
\bar{x} \\
\bar{x}\end{array}$ & $\begin{array}{c}\ddot{\bar{x}} \\
\ddot{\bar{x}} \\
\bar{x}(?)^{1}\end{array}$ & $\begin{array}{l}- \\
\ddot{-} \\
- \\
.-\end{array}$ & $\begin{array}{l}- \\
\ddot{-} \\
\ddot{-} \\
-\end{array}$ & $\begin{array}{l}\ddot{.} \\
\ddot{-} \\
\ddot{-} \\
.\end{array}$ & $\begin{array}{l}- \\
- \\
- \\
- \\
-\end{array}$ & $\begin{array}{l}\mathrm{X} \\
\ddot{x} \\
\ddot{-} \\
\ddot{-}\end{array}$ \\
\hline $\begin{array}{l}\text { Murrayina howei } \ldots \ldots \ldots \ldots \ldots \ldots \\
\quad \text { martini } \ldots \ldots \ldots \ldots \ldots \ldots \ldots \ldots \\
\quad \text { radiata } \ldots \ldots \ldots \ldots \ldots \ldots \ldots \\
\text { Orionina vaughani } \ldots \ldots \ldots \ldots \ldots \\
\text { Otikocythere punctistriata } \ldots \ldots \ldots\end{array}$ & $\begin{array}{l}x \\
x \\
\ddot{x}\end{array}$ & $\begin{array}{l}\ddot{x} \\
-- \\
\ddot{x}\end{array}$ & $\begin{array}{l}- \\
- \\
- \\
- \\
-\end{array}$ & $\begin{array}{l}- \\
-- \\
- \\
- \\
-\end{array}$ & $\begin{array}{l}-. \\
- \\
- \\
- \\
\ddot{-}\end{array}$ & $\begin{array}{l}- \\
- \\
- \\
- \\
-\end{array}$ & $\begin{array}{l}-- \\
\ddot{x} \\
\ddot{x}\end{array}$ \\
\hline $\begin{array}{r}\text { Paracytheridea altila ............. } \\
\text { Peratocytheridea subovata...... } \\
\text { Protocytheretta inaequivalvis ... } \\
\text { Pseudocytheretta burnsi ........ } \\
\quad \text { plebeia } \ldots \ldots \ldots \ldots \ldots \ldots \ldots\end{array}$ & $\begin{array}{l}\ddot{x} \\
x \\
x\end{array}$ & $\begin{array}{l}\ddot{x} \\
\bar{x} \\
\ddot{-}\end{array}$ & $\begin{array}{l}\ddot{-} \\
\ddot{x} \\
\overline{-}\end{array}$ & $\begin{array}{l}\ddot{x} \\
\bar{x} \\
-.\end{array}$ & $\begin{array}{l}X \\
-- \\
- \\
- \\
-\cdot\end{array}$ & $\begin{array}{l}-. \\
- \\
.- \\
.-\end{array}$ & $\begin{array}{l}\mathrm{X} \\
-- \\
.- \\
.- \\
.-\end{array}$ \\
\hline $\begin{array}{l}\text { Pterygocythereis americana..... } \\
\text { Puriana rugipunctata........... } \\
\text { Thaerocythere schmidtae ....... }\end{array}$ & $\begin{array}{l}X \\
-- \\
-.\end{array}$ & $\begin{array}{l}\ddot{-} \\
\ddot{-}\end{array}$ & $\begin{array}{l}- \\
- \\
-\end{array}$ & $\begin{array}{l}- \\
\ddot{-}\end{array}$ & $\begin{array}{l}\ddot{x} \\
x\end{array}$ & $\ddot{x}$ & $\begin{array}{l}\ddot{x} \\
x\end{array}$ \\
\hline
\end{tabular}

${ }^{1}$ Identification uncertain.

Not Clithrocytheridea virginiensis Malkin, 1953, p. 783, pl. 79, figs. 23, 25 (= Cytheridea campwallacensis Hazel, 1977).

?Haplocytheridea sp. aff. H. blanpedi (Stephenson). Swain, 1968, p. 8 , pl. 1, figs. $6 a$, b.

Cytheridea sp. A Swain, 1974 (partim), p. 13, pl. 1, figs. 6, 7; not Cytheridea sp. A Swain, 1974, p. 13, pl. 1, fig. 8 (= Peratocytheridea bradyi (Stephenson, 1938)).

Cytheridea muelleri (Munster) subspecies Swain, 1974, p. 14, pl. 1, fig. 5 .

Cytheridea virginiensis (Malkin). Hazel, 1977, p. 382, fig. g.

Diagnosis. - Greatest length about midvalve and greatest height just anterior of the central muscle scar field; normal pores (in punctae) forming somewhat regular V-shaped patterns in medial area of the valve; three concentric rows of punctae forming concentric furrows along both the anterior and posterior ends of the valve; smaller than Cytheridea diagonalis (Malkin, 1953).

Lectotype.-A male left valve (Malkin, 1953, pl. 79, fig. 28), USNM 256020, from the Yorktown Formation (locality VA-10 of Malkin, 1953) is herein designated as the lectotype (pl. 1, fig. 7).

Measurements. - The lectotype is $770 \mu \mathrm{m}$ in length and $420 \mu \mathrm{m}$ in height.

Remarks.-Cytheridea virginiensis (Malkin, 1953) and a closely related species are illustrated in Hazel (1977; in press). Both species are morphologically similar except that $C$. virginiensis is always smaller and has a somewhat different punctae-normal pore pattern on the lateral surface of the valve. The larger species occurs in units $C$ and $D$ of the Eastover Formation (upper Miocene) and the lower (lower Pliocene) Yorktown Formation. Cytheridea virginiensis occurs throughout the Yorktown Formation and also occurs in upper Pliocene and lower Pleistocene units in the Atlantic Coastal Plain (Hazel, 1977).

Stratigraphic range. - Pliocene to lower Pleistocene.

\section{Cytheridea subovalis (Ulrich and Bassler, 1804)}

Plate 1, figures 1,8

Cythere subovalis Ulrich and Bassler, 1904, p. 111, pl. 38, figs. 14, 15.

Diagnosis.-Subtriangular to oval valve outline; greatest length just below the midheight; greatest height just anterior of central muscle scar field; normal pores (in punctae) form a poorly defined V-shaped pattern on the medial area of the valve; three concentric rows of punctae form three furrows along the anterior margin of the valve, concentric furrows present but poorly defined at the posterior margin of the valve.

Measurements. - The holotype (pl. 1, fig. 8), USNM 35439 , is $840 \mu \mathrm{m}$ in length and $540 \mu \mathrm{m}$ in height. The illustrated specimen (pl. 1, fig. 1), USNM 256021, is $850 \mu \mathrm{m}$ long and $510 \mu \mathrm{m}$ in height.

Remarks.-The species concept of Cytheridea subovalis (Ulrich and Bassler, 1904) is based upon a single poorly preserved valve (pl. 1, fig. 8). This specimen (the holotype) was collected at their Paw Paw Point locality near Leonardtown, Md., from the Choptank Formation. Due to the poor preservation, cogent placement of other specimens in this species is difficult. In my studies of the Choptank Formation no adult Cytheridea has yet been found. Specimens of a Cytheridea from the Calvert Formation at Plum Point (Bed 10) are similar in size and shape to the holotype of C. subovalis and are tentatively placed in this species. 
One of these specimens is illustrated in plate 1, figure 1. This specimen and the others from the Plum Point locality form the material upon which the diagnosis of C. subovalis is based.

Occurrence.-Calvert (see remarks) and the Choptank Formations.

Stratigraphic range.-Lower to middle Miocene.

Genus Peratocytheridea Hazel, in press

Type-species.-Cytheridea setipunctata Brady, 1869.

Peratocytheridea subovata (Ulrich and Bassler, 1904)

Plate 1, figure 4

Cytheridea subovata Ulrich and Bassler, 1904, p. 124, pl. 37, figs. 1-8.

Not Haplocytheridea? cf. H.? subovata (Ulrich and Bassler). Swain, 1951 , p. 22, pl. 1, figs. 19, 20.

Haplocytheridea subovata (Ulrich and Bassler). Malkin, 1953, p. 782, pl. 79, figs. 15, 17; Sandberg, 1964, p. 359, pl. 1, figs. 1-9 (gives more complete synonymy).

Diagnosis. -Subovate valve outline; greatest length along midvalve and greatest height in central muscle scar area; finely punctate lateral surface with punctae containing the normal pores; posterior acute.

Measurements. - The illustrated paralectotype (pl. 1, fig. 4), USNM 648513, is $880 \mu \mathrm{m}$ in length and $480 \mu \mathrm{m}$ in height. The lectotype, USNM 35445 , is $870 \mu \mathrm{m}$ in length and $490 \mu \mathrm{m}$ in height.

Remarks.-Peratocytheridea subovata (Ulrich and Bassler, 1904) comprises a complex group of sizes and morphologies. The lectotype and paralectotype (Sandberg, 1964, chose the lectotype from Ulrich and Bassler's syntype suite) are from bed 10 of the Calvert Formation at Plum Point, Md. The Calvert forms are generally small specimens ranging in size from 750 to $900 \mu \mathrm{m}$ in length, and the females are smaller than the males. In contrast, specimens from the Choptank Formation are usually within a range of from 920 to 1,200 $\mu \mathrm{m}$ in length, the females again being smaller. Units A and $B$ of the St. Marys Formation contain forms intermediate in size (ranging from 850 to $930 \mu \mathrm{m}$ (between the Calvert and Choptank specimens. This sizetime relationship has also been observed in correlative sediments in Florida (Sandberg, 1964).

Sandberg's (1964) illustrated adults were all from the Shoal River Formation of Florida. These specimens represent the large version of $P$. subovata (Ulrich and Bassler) common to the Choptank Formation. At present no obvious explanation can be advanced for these size differences.

Occurrence. - Ulrich and Bassler (1904) reported this species from the Calvert Formation. Malkin (1953) notes the occurrence of this species in both the Calvert and Choptank Formations. I have found Peratocytheridea subovata occurring commonly in the Calvert, Choptank and units A and B of the St. Marys Formations.

Stratigraphic range. - Lower to middle Miocene. Family NEOCYTHERIDEIDAE Puri, 1957

Genus Hulingsina Puri, 1958

Type-species.-Hulingsina tuberculata Puri, 1958.

Hulingsina calvertensis new species

Plate 1, figures 2, 5

Cytherideis ashermani Ulrich and Bassler, 1904, p. 126, pl. 37, fig. 15.

Cushmanidea fabula (Howe and Dohm). Swain, 1974, p. 15, pl. 1, fig. 20; pl. 8, figs. $4 a$, b.

Not Cytherideis ashermani Ulrich and Bassler, 1904, p. 126, pl. 37, figs. 11-14, 16; Howe and others, 1935, p. 14, pl. 3, figs. 8-10; Malkin, 1953, p. 778, pl. 78, figs. 1-13; Puri, 1954, p. 286, pl. 9, figs. 4-8. (= Hulingsina spp., primarily $H$. semicircularis (Ulrich and Bassler, 1904)).

Not Cushmanidea ashermani (Ulrich and Bassler). McLean, 1957, p. 77, pl. 18, figs. 5a-f. (= Hulingsina sp.)

Not Pontocythere ashermani (Ulrich and Bassler). Swain, 1968, p. 10, pl. 2, figs. 1a-d. (= Hulingsina sp.)

Not Pontocythere (Hulingsina) ashermani (Ulrich and Bassler). Swain, 1974, p. 16, pl. 1, figs. 21, 24; pl. 2, figs. 1-3; pl. 9, figs. 12a, b. (= Hulingsina sp.)

Diagnosis.-Subquadrate shape; very oblique anterodorsal margin; predominantly smooth valves (particularly in the anterior); diagnostic punctae pattern in the posteromedial area of the valve where the pattern consists of five punctae forming an isosceles triangle that points toward the posterior, with three additional punctae located posterodorsally from the posterior-most point of the triangle.

Etymology.-The trivial name is after the Calvert Formation in which the holotype occurs.

Holotype.-A female left valve (pl. 1, fig. 2), USNM 256022, from "zone" 10 of the Calvert Formation, 0.5 miles north of Randle Cliffs, 10 feet above the water level on the west side of Chesapeake Bay, Calvert County, Md.

Measurements.-The holotype is $775 \mu \mathrm{m}$ in length and $375 \mu \mathrm{m}$ in height.

Remarks.-The syntype suite of four specimens (only one was illustrated by Ulrich and Bassler, 1904) for Cytherideis ashermani Ulrich and Bassler, 1904, represents three species. There are two poorly preserved juvenile specimens, which, in my opinion, represent Hulingsina subaequalis (Ulrich and Bassler, 1904). A third specimen, also poorly preserved, is conspecific with $H$. semicircularis (Ulrich and Bassler, 1904) (see discussion under that species). The fourth specimen represents a valid species that is a common 
constituent of assemblages in the Miocene part of the Chesapeake Group. It was illustrated by Ulrich and Bassler (1904, plate 37, figure 15), and subsequently by Swain (1974), where it was erroneously classified under Cushmanidea fabula (Howe and Dohm, 1935) in Howe and graduate students (1935). There were other specimens illustrated by Ulrich and Bassler (1904), but these have apparently been lost.

I had originally planned to designate the specimen illustrated by Ulrich and Bassler (1904, pl. 37, fig. 15) as the lectotype of Cytherideis ashermani Ulrich and Bassler, and thereby conserve that trivial name. Unfortunately, the Ulrich and Bassler specimen was lost after the scanning electron micrograph shown on plate 1 , figure 5 (this report) was taken. As noted above, the other specimens of the syntype suite were not illustrated and are either juveniles or clearly another described species (Hulingsina semicircularis). Furthermore, the trivial name ashermani has never been consistently used for any valid taxon occurring in the Chesapeake Group. In fact, the name ashermani has been used for several distinctive species of Hulingsina occurring in sediments ranging in age from early Miocene to Holocene. Hulingsina ashermani represents a group of species sharing a generally similar ornament rather than any one species.

In view of the situation outlined above, I feel that it is best to: (1) propose a new species that would include the lost specimen illustrated by Ulrich and Bassler as part of their Cytherideis ashermani, (2) designate as the lectotype of $C$. ashermani the unillustrated adult specimen from the syntype suite (this specimen is cataloged as USNM 35446), and (3) subjectively suppress Cytherideis ashermani by placing it in synonymy with Hulingsina semicircularis. This action is further warranted because the Ulrich and Bassler (1904) illustrations (pl. 37; figures 11-16) indicate that their concept of Cytherideis ashermani involved at least Hulingsina calvertensis and several poorly preserved specimens of $\boldsymbol{H}$. semicircularis. If later workers disagree with this assessment that the lectotype of Cytherideis ashermani is synonymous with Hulingsina semicircularis, the trivial name ashermani can be revived.

Occurrence.-Hulingsina calvertensis occurs throughout the Miocene part of the Chesapeake Group.

Stratigraphic range.-Lower to upper Miocene.

\section{Hulingrina rugipustulosa (Edwards, 1944)}

Plate 2, figure 1

Cytherideis rugipustulosa Edwards, 1944, p. 514, pl. 86, figs. 5-7. Cytherideis echolsae Malkin, 1953, p. 778, pl. 78, figs. 14-17.
?Cushmanidea echolsae (Malkin). McLean, 1957, p. 78, pl. 9, figs. 1a-c, 2a-d.

Pontocythere rugipustulosa (Edwards). Swain, 1968, p. 9, pl. 1, fig. 10.

Hulingsina rugipustulosa (Edwards). Valentine, 1971, pl. 3, figs. 17, $18,21,22,25,26,29,30$.

Pontocythere (Hulingsina) rugipustulosa (Edwards). Swain, 1974, p. 17 , pl. 1, fig. 18; pl. 2, figs. 4-7.

Diagnosis.-Distinguished by its generally small size, elongate subrectangular valve outline, rugose nature of the primary ornament (often leaving the appearance of the valve surface being wrinkled), and variation with respect to the presence of pustules along the carinae.

Lectotype. -A male right valve (Malkin, 1953, pl. 78, fig. 15), USNM 256023, from the Yorktown Formation (locality VA-12 of Malkin, 1953) is herein selected as the lectotype of Cytherideis echolsae Malkin, 1953 (pl. 2, fig. 1).

Measurements. - The lectotype is $650 \mu \mathrm{m}$ in length and $250 \mu \mathrm{m}$ in height.

Remarks.-Hulingsina rugipustulosa (Edwards, 1944) is typically represented by two morphologies (also see Valentine, 1971), a pustulose form described by Edwards (1944) as Cytherideis rugipustulosa and a nonpustulose form described by Malkin (1953) as Cytherideis echolsae. The carinae and normal pores of both forms seem identical in pattern. Occurrence data suggest that the nonpustulose form tends to be a more cryophilic form, whereas the pustulose form is more thermaphilic. Both forms commonly occur in the same modern samples in the subtropical Carolinian Faunal Province, but only the nonpustulose form occurs north of Cape Hatteras in the mild temperate Virginian Province (J. E. Hazel, written commun., 1976).

Occurrence.-Malkin (1953) reported this species from the Yorktown Formation in Virginia. In my samples from the Chesapeake Group the nonpustulose form is found in units C and D of the Eastover Formation and in the Yorktown Formation.

Stratigraphic range.-Upper Miocene to Holocene.

Hulingsina cylindrica (Ulrich and Bassler, 1904)

Plate 2, figure 2

Cytheridea cylindrica Ulî̀ich and Bassler, 1904, p. 126, pl. 37, fig. 17.

Diagnosis. -Quadrate valve outline; sulcus along the line of the central muscle scar field; prominent reticulum.

Measurements. - The holotype (pl. 2, fig. 2), USNM 35447 , is $890 \mu \mathrm{m}$ in length and $370 \mu \mathrm{m}$ in height.

Remarks. -Hulingsina cylindrica is similar to many other reticulate species of Hulingsina; however, it is 
usually more coarsely reticulate, with a reticulum that covers the entire lateral surface, except for the medial dorsal part of the valve. The species, taken in a strict sense, may be confined to the Calvert Formation and represent a very rare component of the ostracode fauna. There is, however, a very similar but somewhat larger form in the Choptank and St. Marys Formations. The Choptank forms average 1,030 $\mu \mathrm{m}$ in length; the St. Marys form averages $900 \mu \mathrm{m}$ in length. This younger form is probably conspecific with the Calvert form because an increase in size of several species from the Calvert to the Choptank Formations has been noted.

Occurrence.-Calvert Formation and probably the Choptank Formation, as well as units A and B of the St. Marys Formation.

Stratigraphic range.-Lower to middle Miocene.

Hulingsina semicircularis (Ulrich and Bassler, 1904)

Plate 2, figure 5

Cytherideis semicircularis Ulrich and Bassler, 1904, p. 127, pl. 37, figs. 18-20.

Cytherideis longula Ulrich and Bassler, 1904, p. 128, pl. 37, figs. 21-27.

Cytherideis ashermani Ulrich and Bassler, 1904, partim, p. 126, pl. 37, figs. 11-13; Howe and others, 1935, p. 14, pl. 3, figs. 8-10; Malkin, 1953, partim, p. 778, pl. 78, figs. 1-11, 13?; Puri, 1953, partim, p. 286 , pl. 9 , figs. $4,5,7,8$.

Diagnosis. - This species is distinguished by its somewhat semicircular valve outline, greatest length below midheight, greatest height (midvalve) behind the adductor muscle scar field, prominent large punctae containing normal pores.

Lectotype.-A female right valve, USNM 35449 a, is designated as the lectotype. This specimen is probably that illustrated by Ulrich and Bassler (1904) on plate 37, figure 18. The syntype series is from the Calvert Formation at Plum Point, Md.

Measurement.-The lectotype is $760 \mu \mathrm{m}$ in length and $350 \mu \mathrm{m}$ in height.

Remarks. - The specimens assigned to Cytherideis semicircularis by Ulrich and Bassler (1904) are all females (as has been noted by many authors). I believe the male of the species was described by Ulrich and Bassler as Cytherideis longula and therefore, synonomize the two species, retaining the trivial name semicircularis. A left valve, which is probably the specimen illustrated by Ulrich and Bassler (1904) on plate 37 , figure 25 , USNM 35448 a, is designated as the lectotype of Hulingsina longula (Ulrich and Bassler, 1904). The lectotype is illustrated herein on plate 2 , figure 3 and a paralectotype is illustrated in plate 2 , figure 4. The lectotype is $940 \mu \mathrm{m}$ in length and $380 \mu \mathrm{m}$ in height, while the illustrated paralectotype, USNM $35448 \mathrm{~b}$, is $850 \mu \mathrm{m}$ in length and $330 \mu \mathrm{m}$ in height.
My concept is, however, that $H$. semicircularis (Ulrich and Bassler) is equivalent in part to Cytherideis ashermani of some authors. The $C$. "ashermani syntype series represents three species (see discussion under Hulingsina calvertensis), and it is not clear what their concept of the species was. The $C$. semicircularis series contains only one species, in my opinion; at least for the females, Ulrich and Bassler's concept of them is clear. One of the specimens in the syntype series of Cytherideis ashermani, herein designated the lectotype of that species, is placed in synonymy of $H$. semicircularis.

Hulingsina semicircularis is a common constituent of Calvert, Choptank and St. Marys (units A and B) assemblages, becoming somewhat rarer in the younger Miocene (Eastover Formation) sediments (units $\mathrm{C}$ and D). As with several other ostracode species occurring in both the Calvert and Choptank Formations, the mean size of the Choptank form is larger.

Hulingsina semicircularis (Ulrich and Bassler) is morphologically similar to $H$. americana (Cushman, 1906). Pleistocene and Holocene specimens of the latter species are readily distinguished from $H$. semicircularis by their narrower murae, prominent normal pores, and slight differences in valve outline. However, Pliocene specimens are morphologically somewhat gradational, exhibiting only slightly greater morphologic similarity with $H$. americana. My concept of $H$. semicircularis restricts the species to the Miocene; however, considerable difficulty is encountered in trying to classify some specimens from the lower part of the Yorktown Formation.

Occurrence.-Calvert, Choptank, and St. Marys and Eastover Formations.

Stratigraphic range.-Lower to upper Miocene.

Hulingsina subaequalis (Ulrich and Bassler, 1904)

Plate 2, figure 6

Cytherideis subaeqalis Ulrich and Bassler, 1904, p. 127, pl. 37, fig. 28; Malkin, 1953, partim, p. 779, pl. 78, fig. 18.

Diagnosis. -This species is distinguished by its quadrate shape; height approximately half the length; few, scattered punctae with normal pores.

Measurements. - The holotype USNM 35450 (female left valve, pl. 2, fig. 6), is $840 \mu \mathrm{m}$, in length and 420 $\mu \mathrm{m}$ in height.

Occurrence.-Ulrich and Bassler (1904) reported this species from the Calvert Formation. Malkin (1953) reported it from the Calvert and Choptank Formations, but her illustrated specimens are all from the Calvert Formation. In my samples, Hulingsina subaequalis occurs in the Calvert below "zone" 11.

Stratigraphic range.-Lower Miocene. 
Family CYTHERURIDAE G. W. Muller, 1894

Subfamily CYTHERURINAE G. W. Muller, 1894

Genus Cytherura Sars, 1866

Type-species. -Cytherura gibba O. F. Muller, 1785.

Cytherura coryelli Malkin, 1953

Plate 2, figure 8

Cytherura coryelli Malkin, 1953, p. 788, pl. 80, figs. 20, 21, 25.

Diagnosis. - Height to length ratio of 0.5 or greater, greatest height just posterior to the adductor muscle scar field; punctation that covers the entire valve surface and forms concentric rows along the dorsal and ventral margins; hingement consisting of an anterior socket, crenulate tooth, crenulate bar, and another crenulate tooth in the left valve.

Lectotype.-A female left valve (Malkin, 1953, pl. 80, fig. 25), USNM 256024, from the Choptank Formation (locality 14-5 of Malkin, 1953) is herein designated as the lectotype (pl. 2, fig. 8).

Measurements. - The lectotype is $450 \mu \mathrm{m}$ in length and $250 \mu \mathrm{m}$ in height.

Occurrence.-Malkin (1953) reported this species from the Choptank Formation. It also occurs in unit B of the St. Marys Formation in my collections, as well as in the Choptank Formation.

Stratigraphic range.-Middle Miocene.

Subfamily CYTHEROPTERINAE Hanai, 1957

Genus Cytheropteron Sars, 1866

Type-species._Cythere latissima Norman, 1865

Cytheropteron? yorktownensis (Malkin, 1953)

Plate 2, figure 7

Eocytheropteron? species Swain, 1951, p. 47, pl. 7, fig. 16.

Eocytheropteron yorktownensis Malkin, 1953, p. 780, pl. 79, figs. $1-4$.

Cytheropteron leonensis Puri, 1954, p. 242, pl. 4, figs. 11, 12; figs. $6 c, d$.

Cytheropteron yorktownensis (Malkin). Swain, 1968, p. 13, pl. 4, figs. $7 \mathrm{a}-\mathrm{c}, 11$.

Shattuckocythere yorktownensis (Malkin). Swain, 1974, p. 22, pl. 3, figs. 9-12, 14, 15 .

Not Shattuckocythere yorktownensis (Malkin).-Swain, 1974, p. 22, pl. 3, fig. 13; pl. 9, figs. 9a, b (=Microcytherura similis (Malkin)).

Diagnosis. -Small size; subtrapezoidal valve outline; in having the greatest height anterior to the adductor muscle scar field; ventral medial portion of the valve inflated and overhanging ventral valve margin; prominent ornamentation pattern consisting of a subdued reticulum with numerous fine punctae covering the solum of each fossa.

Lectotype.-A female left valve (Malkin, 1953, pl. 79, fig. 3), USNM 256025, (locality VA-4, of Malkin,
1953), is herein designated as the lectotype (pl. 2, fig. 7).

Measurements. -The lectotype is $390 \mu \mathrm{m}$ in length and $220 \mu \mathrm{m}$ in height.

Remarks.-Cytheropteron? yorktownensis (Malkin, $1953)$ is a very distinctive and common species in Pliocene sediments along the Atlantic Coastal Plain. It is probably sufficiently distinctive from the $C y$ theropteron to be placed in a new genus, although its familial assignment is uncertain at present. Swain (1974) assigned C.? yorktownensis to his new genus Shattuckocythere. However, Shattuckocythere is not a useful taxon because the type species selected by Swain (Cythere? shattucki Ulrich and Bassler, 1904) is a typical member of the genus Microcytherura Mueller, 1894.

Occurrence.-In the Chesapeake Group the species has been found only in the Yorktown Formation. It also occurs in Atlantic Coastal Plain deposits of early Pleistocene age.

Stratigraphic range.-Pliocene to lower Pleistocene.

Family TRACHYLEBERIDIDAE Sylvester-Bradley, 1948

Subfamily TRACHYLEBERIDINAE Sylvester-Bradley, 1948

Tribe TRACHYLEBERIDINI Sylvester-Bradley, 1948

Genus Murrayina Puri, 1954

Type-species.-Murrayina howei Puri, 1954.

Remarks. -The genus Murrayina is comprised of a group of reticulate Trachyleberidini closely related to Actinocythereis. The morphologic bounds of the species within this genus, for the most part, are poorly understood, particularly when populations are examined that are geographically or temporally disjunct from the type area of the species in question. Murrayina either consists of a few species with a great deal of morphologic variability or numerous species with little variability (or perhaps both). The genus has a known range of early Miocene to early Pleistocene and is recognized by its rectangular shape (i.e., Actinocythereis), its usually distinctive reticulum, and the presence of a denticular structure on the ventral inner margin of the right valve (also developed to varying degrees in Actinocythereis). The close relationship of Murrayina to Actinocythereis is exemplified by Murrayina radiata (Malkin, 1953), which has certain features that are practically intermediate between typical Actinocythereis and typical Murrayina.

The confusion associated with the morphologic definition of the various species of Murrayina is further compounded by the preservational states of $M u r-$ rayina. In surface morphology, specimens may range from strongly reticulate to completely smooth; however, smooth exterior surfaces seem to be the 
result of post-mortem processes. Diagenetic changes (the causes of which are poorly understood at present) seem to have progressively removed some or all of the reticulation, resulting in a smooth-valved specimen as an end product. I have observed specimens of several species of Murrayina in various states of alteration, with the reticulum "exfoliating" off the valve. Murrayina is in need of extensive morphologic study; this is beyond the scope of the present work.

\section{Murrayina howei Puri, 1954}

Plate 3, figure 3

Cythere producta Ulrich and Bassler, 1904, p. 115, pl. 36, fig. 17; pl. 38, figs. 28-30.

Cythere dorsicornis Ulrich and Bassler, 1904, p. 113, pl. 36, fig. 13.

Not Cythereis producta Howe and others, 1935, p. 22, pl. 1, figs. $31,32,35-37$; pl. 4, figs. 11, 12 (?= male of Murrayina gunteri).

Not Murrayina howei Puri, 1954, p. 255, pl. 12, figs. 9, 10; figures $8 \mathrm{~g}$, h; McLean, 1957 , p. 85 , pl. 10, figs. $4 \mathrm{a}-\mathrm{e}$.

Diagnosis. - Rectangular valve outline; very prominent reticulum, with narrow murae forming each fossa; broad smooth areas concentric with the anterior and posterior of the valve; large size.

Lectotype.-A male right valve, which is probably the specimen illustrated by Ulrich and Bassler (1904) on pl. 38, fig. 30, USNM 35433 a, is designated the lectotype (pl. 3, fig. 3). This specimen occurs at the Plum Point locality (Ulrich and Bassler, 1904) of the Calvert Formation.

Measurements. - The lectotype measures $980 \mu \mathrm{m}$ in length and $400 \mu \mathrm{m}$ in height.

Remarks.-Murrayina howei is very similar to $M$. martini (Ulrich and Bassler, 1904), but the former is larger and has polygonal fossae, whereas the fossae in $M$. martini are elliptical in outline and are relatively smaller.

The nomenclatural history of this species is quite complex. Ulrich and Bassler's Cythere producta is a junior homonym of $C$. producta Brady, 1866. Puri (1954) recognized this and renamed the species Murrayina howei, making it the type species of that genus. In my opinion, it is quite possible that the form identified by Puri (1954) and Howe and others (1935) as Ulrich and Bassler's Cythere producta may be the male of Murrayina gunteri (Howe and Chambers, 1935). Hazel (1967, p. 22) thought that Murrayina gunteri and $M$. howe $i$ were synonyms and therefore the former would have priority over Puri's (1954) name $M$. howei. However, work by the author on the genus Murrayina has led to the conclusion that $M$. gunteri is a distinct species and $M$. howei is retained for Cythere producta Ulrich and Bassler, 1904.
The juveniles of the species differ from the adults in shape and possess two prominent spines in the posterior of the valves. Cythere dorsicornis Ulrich and Bassler, 1904, is a typical juvenile of $M$. howei Puri, 1954. The holotype of $C$. dorsicornis Ulrich and Bassler, 1904, is illustrated in plate 3 , figure 5 and is $670 \mu \mathrm{m}$ in length and $360 \mu \mathrm{m}$ in height.

Occurrence.-This species was reported from the Calvert Formation by Ulrich and Bassler (1904). It has been reported from younger sediments by other authors, but I believe that these reports represent other species. Murrayina howei occurs throughout the Calvert Formation in my collections, but has not been observed in younger units.

Stratigraphic range.-Lower to middle Miocene.

\section{Murrayina martini (Ulrich and Bassler, 1904)}

Plate 3, figures 2, 4

Cythere martini Ulrich and Bassler, 1904, p. 112, pl. 36, figs. 11-15. ?Cythere dorsicornis var. bicornis Ulrich and Bassler, 1904, p. 114, pl. 38, figs. 32, 33 .

Not Trachyleberis? martini (Ulrich and Bassler). Swain, 1951, p. 29, pl. 3, figs. 8, 15; Malkin, 1953, p. 793, pl. 82, figs. 6-13.

Not Murrayina martini (Ulrich and Bassler). Puri, 1954, p. 256, pl. 12, figs. 8e, f, 11-13; McLean, 1957, p. 86, pl. 11, figs. 1a-c, $2 a-b, 3 a-d$.

Diagnosis.-Valve outline quadrate; prominent reticulum with fairly wide murae and oval-shaped fossae; narrow smooth areas concentric to the anterior and posterior margins.

Lectotype. - A male right valve illustrated by Ulrich and Bassler (1904, pl. 36, fig. 13), USNM 35423 a, from the Calvert Formation at Plum Point, Md., is selected as the lectotype (pl. 3, fig. 2).

Measurements. - The lectotype is $710 \mu \mathrm{m}$ in length and $310 \mu \mathrm{m}$ in height. The illustrated paralectotype, USNM $35423 \mathrm{~b}$, (pl. 3, fig. 4), a female left valve, is $710 \mu \mathrm{m}$ in length and $410 \mu \mathrm{m}$ in height.

Remarks. - Hazel (1967) deals with the complicated nomenclatural history of Murrayina martini. The majority of the species referred to $M$. martini by various authors represent several species of the genus Muellerina of the family Hemicytheridae.

Murrayina martini as defined herein has not been reported from sediments younger than the Choptank Formation. In fact, in my collections of Choptank sediments $M$. martini only occurs in "zones" 16 and 17 of the Choptank Formation. Morphologically similar forms, occurring in younger sediments, could easily be confused with $M$. martini; I regard them as being one or more undescribed species.

Cythere dorsicornis var. bicornis Ulrich and Bassler, 1904 , like $C$. dorsicornis sensu stricto, represents a 
Murrayina instar. The holotype USNM 35416, illustrated here (pl. 3, fig. 6; $430 \mu \mathrm{m}$ in length and $250 \mu \mathrm{m}$ in height), comes from the Choptank Formation at the "Paw Paw Point" locality of Ulrich and Bassler (1904). The reticulation is developed in a manner most similar to that seen in adults of Murrayina martini and therefore $M$. bicornis is placed in synonymy with $M$. martini.

Occurrence.-This species occurs commonly in collections from the Calvert and Choptank Formations.

Stratigraphic range.-Lower to middle Miocene.

Murrayina radiata (Malkin, 1953)

Plate 3, figure 1

Trachyleberis radiata Malkin, 1953, p. 791, pl. 81, figs. 12, 13.

Not Trachyleberis radiata Malkin, 1953, p. 791, pl. 81, fig. 14 (= Murrayina howei (Ulrich and Bassler)).

Diagnosis.-Valve outline quadrate; prominent reticulum, with polygonal to irregularly shaped fossae; large carinae radiating from the central muscle node toward the posterior margin and medial ventral area, terminating in blunt denticles; prominent dorsal carina, which overhangs the dorsal margin; smooth area concentric to the anterior margin.

Lectotype.-A female right valve illustrated by Malkin (1953, pl. 81, fig. 12), USNM 256026, from the Kirkwood Formation of New Jersey (locality NJ-9 of Malkin, 1953) is designated the lectotype (pl. 3, fig. 1).

Measurements. -The lectotype is $780 \mu \mathrm{m}$ in length and $380 \mu \mathrm{m}$ in height.

Remarks. - Murrayina radiata exhibits a transitional morphology between Actinocythereis and Murrayina (see remarks above under Murrayina). This species is morphologically similar in reticulation pattern to the other species of Murrayina occurring in the Calvert Formation (compare pl. 3, figs. 1-4). These taxa differ from each other only in a few morphologic characteristics such as size or expression of a carina. Murrayina presumably originated in the Oligocene or early Miocene and thus the strong morphologic similarity of these lower to middle Miocene species $(M$. radiata, $M$. howei, and $M$. martini) may be because of the limited morphologic radiation from a common ancestor.

Occurrence.-Malkin (1953) reported this species from the Kirkwood and Calvert Formations. It represents a fairly rare component of the Calvert fauna.

Stratigraphic range.-Lower to middle Miocene.

Genus Actinocythereis Puri, 1954

Type-species.-Cythere exanthemata Ulrich and Bassler, 1904.
Actinocythereis exanthemata (Ulrich and Bassler, 1804)

Plate 3, figures 7, 8

Cythere exanthemata Ulrich and Bassler, 1904, p. 117, pl. 36, figs. 1-3, 5.

Not Cythere exanthemata Ulrich and Bassler, 1904, p. 117, pl. 36, fig. 4 (= Actinocythereis marylandica (Howe and Hough, 1935)).

Not Trachyleberis exanthemata (Ulrich and Bassler). Swain, 1951, p. 37, pl. 6, fig. 5; Malkin, 1953, p. 791, pl. 81, fig. 19.

Trachyleberis exanthemata (Ulrich and Bassler). Malkin, 1953, p. 791, pl. 81, fig. 19.

Not Actinocythereis exanthemata (Ulrich and Bassler). Puri, 1954, p. 252, pl. 13, figs. 6-13 (= Actinocythereis spp.); McLean, 1957 , p. 82, pl. 10, figs. 1a-c (= Actinocythereis spp.); Swain, 1968 , p. 14 , pl. 2, figs. 5a-f, 12 (= Actinocythereis capitonis Hazel); Swain, 1974, p. 30, pl. 4, figs. 23, 24; pl. 5, figs. 1, 2; pl. 10, figs. 1a-g (= Actinocythereis spp.)

Diagnosis.-Distinctive arrangement of various surface spines: a posterodorsally oriented row of five spines occur along a weakly developed ridge located near the ventral margin; the two anterior-most of these clavate spines are located directly below the central muscle node, the posterior three are bullate in shape and positioned spines in the medial ventral area of the valve; the valve midline is marked by a longitudinal curved row of four spines, directly posterior of the central muscle node. The geometric relationship of these nine spines to each other is constant and unique for this species.

Lectotype. - A female left valve (Ulrich and Bassler, 1904, pl. 36, fig. 3), USNM 35419 a, from the Calvert Formation at Plum Point, Md., is selected as the lectotype (pl. 3, fig. 8).

Measurements.-The lectotype is $850 \mu \mathrm{m}$ in length and $400 \mu \mathrm{m}$ in height; the illustrated paralectotype, USNM $35419 \mathrm{~b}$ (pl. 3, fig. 7), is $800 \mu \mathrm{m}$ in length and $400 \mu \mathrm{m}$ in height.

Remarks.-Actinocythereis exanthemata is most frequently confused with the lower Miocene to Holocene species $A$. marylandica (Howe and Hough, 1935). Actinocythereis marylandica is a larger and more robust form that has a slightly different arrangement of the nine spines discussed above.

Occurrence.-Actinocythereis exanthemata occurs throughout the Calvert Formation and is also known from the lower part of the Choptank Formation ("zone" 17) in my collections.

Stratigraphic range.-Lower to middle Miocene.

Actinocythereis alaris (Ulrich and Bassler, 1804)

Plate 4, figure 3

Cythereis alaris Ulrich and Bassler, 1904, p. 123, pl. 38, figs. 34, 35, 36.

Measurements.-The holotype, USNM 35451, is $730 \mu \mathrm{m}$ in length and $390 \mu \mathrm{m}$ in height. 
Remarks. -Cythereis alaris Ulrich and Bassler, 1904 represents a rather early instar of a species of $A c$ tinocythereis from the Yorktown Formation. However, it cannot be specifically differentiated with certainty and therefore the binomen Cythereis alaris is considered to be nomen dubium.

\section{Genus Henryhowella Puri, 1957}

Type-species.-Cythere evax Ulrich and Bassler, 1904.

Henryhowella evax (Ulrich and Bassler, 1804)

Plate 4, figures 1,2

Cythere evax Ulrich and Bassler, 1904, p. 119, pl. 36, figs. 6-8. Cythere evax var. oblongula Ulrich and Bassler, 1904, p. 119, pl. 36, figs. 9, 10.

Cythere spiniplicata Ulrich and Bassler, 1904, p. 120, pl. 38, fig. 18.

Trachyleberis evax (Ulrich and Bassler). Swain, 1951, p. 28, pl. 3, figs. 2, 3; Malkin, 1953, p. 792, pl. 82, figs. 4, 5.

?Trachyleberis evax (Ulrich and Bassler). Swain, 1951, p. 28, pl. 3, fig. 1.

Not Echinocythereis evax (Ulrich and Bassler). Puri, 1954, p. 260, pl. 12, fig. 1; fig. 9c.

Not Howella evax (Ulrich and Bassler). Puri, 1956, p. 275, pl. 35, figs. 1-8.

?Henryhowella evax (Ulrich and Bassler). Pooser, 1965, p. 59, pl. 19, fig. 1; pl. 20, figs. 2, 7, 9-13.

Diagnosis.-Large valve size; characteristic quadrate shape; three primary longitudinal carinae; numerous small bifurcating spines; development of a reticulum from the central muscle area of the valve to the valve anterior.

Lectotype. - A female left valve illustrated by Ulrich and Bassler (1904, pl. 36, fig. 7), USNM 35417 a, from the Calvert Formation, Plum Point, Md., is selected as the lectotype (pl. 4, fig. 2).

Measurements. -The lectotype is $770 \mu \mathrm{m}$ in length and $450 \mu \mathrm{m}$ in height.

Remarks.-Henryhowella species are usually morphologically quite similar to each other. Carapace size and minor details of the ornament appear to be important characteristics for differentiating the various species. The species identified by Puri $(1954,1956)$ from upper Miocene and Pliocene sediments as Henryhowella evax is smaller and has a slightly different shape than specimens from the Calvert Formation. Cythere evax var. oblongula Ulrich and Bassler, 1904 is the male of Henryhowella evax. A left valve (Ulrich and Bassler, 1904, pl. 36, fig. 10), USNM 35418 a, from the Calvert Formation, Plum Point, Md., is selected as the lectotype. The lectotype is $860 \mu \mathrm{m}$ in length and $450 \mu \mathrm{m}$ in height.

Only a fragment of the holotype of Cythere spiniplicata Ulrich and Bassler, 1904, USNM 35438, exists. The fragment is part of the valve just behind the cen- tral muscle node. This fragment appears to be a Henryhowella, probably $H$. evax, and thus this species is synonymized under $H$. evax.

Occurrence. -Ulrich and Bassler (1904) reported this species from the Calvert Formation and from the Yorktown Formation; however, subsequent authors have not found the genus in the Yorktown Formation (Hazel, 1971). I have only found this species in the Calvert Formation. Pooser (1965) reports this species from the upper part (upper Oligocene) of the Cooper Formation in South Carolina.

Stratigraphic range-Upper Oligocene to middle Miocene.

Tribe PTERYGOCYTHEREIDINI Puri, 1957

Genus Pterygocythereis Blake, 1983

Type-species. -Cythereis jonesii Baird, 1850

Pterygocythereis americana (Ulrich and Bassler, 1804)

Plate 4, figure 4

Cythereis cornuta var. americana Ulrich and Bassler, 1904, p. 122, pl. 37, figs. 29-33.

Not Cythereis (Pterygocythereis) cornuta var. americana (Ulrich and Bassler). Howe and others, 1935, p. 26, pl. 2, figs. 19, 21-24; pl. 4, fig. 24.

?Pterygocythereis cornuta americana (Ulrich and Bassler, 1904). Puri, 1954, partim, p. 261, pl. 13, fig. 5.

Pterygocythereis americana (Ulrich and Bassler, 1904). Malkin, 1953, partim, p. 795, pl. 80, fig. 29.

Not Pterygocythereis americana (Ulrich and Bassler, 1904). McLean, 1957 , p. 80, pl. 9, figs. 5a-d, 6a-e; Swain, 1974, p. 23, pl. 2, fig. 11; pl. 9, fig. 5; pl. 13, figs. 2a-c (= Pterygocythereis inexpectata Blake, 1933).

Diagnosis.-Distinguished by its quadrate valve outline, valve size, details of the dorsal crests, and the position and nature of the ala. The two dorsal crests are approximately equidimensional and generally nonplicated; ala parallels and overhangs the ventral margin and is usually wide enough that it is not plicated; ala is connected to the posteroventral area of the valve by a short, but prominent, posterodorsally oriented ridge.

Lectotype.-A female left valve (Ulrich and Bassler, 1904, pl. 37, fig. 31 (?)), USNM 35452 a, from the Calvert Formation at Plum Point, Md., is selected as the lectotype.

Measurements.-The lectotype (pl. 4, fig. 4) is $950 \mu \mathrm{m}$ in length and $530 \mu \mathrm{m}$ in height.

Remarks.-Pterygocythereis americana appears to represent an intermediate morphologic stage between $P$. howei Hill, 1954 (from the Oligocene) and $P$. inexpectata Blake, 1933, an upper Miocene to Holocene species. Pterygocythereis howei differs from $P$. americana in having dorsal crests of unequal length, where the posterior crest is longer than the anterior crest. The alae of $P$. howei are relatively thicker and 
are located closer to the medial part of the valve (higher on the valve) than in $P$. americana. Pterygocythereis americana differs from $P$. inexpectata in having relatively thicker alae that are located more medially (higher) on the valve surface. The dorsal crests of both species are about the same length, although those in $P$. americana are relatively thicker than those in $P$. inexpectata. The valve outline of the $P$. howei to $P$. inexpectata sequence also changes by becoming progressively less quadrate and more rectangular, where $P$. howei has a greater height to length ratio than $P$. inexpectata.

The upper Miocene (unit D of the Eastover Formation), Pliocene, and Quaternary specimens of $P$. inexpectata are readily distinguished from Calvert specimens of $P$. americana (lower to middle Miocene) by the characteristics noted above. However, there are a number of intermediate forms occurring in units B and $\mathrm{C}$ of the St. Marys Formation (upper middle and upper Miocene) that could be placed in either species. These morphologically intermediate specimens are herein arbitrarily placed in $P$. inexpectata. As yet no Pterygocythereis species have been found in the Choptank Formation, thus providing a slight and somewhat arbitrary morphologic gap to subdivide the species.

Occurrence.-Pterygocythereis americana is confined to the Calvert Formation in our collections.

Stratigraphic range.-Lower to middle Miocene.

\section{Tribe ECHINOCYTHEREIDINI Hazel, 1967}

Genus Echinocythereis Puri, 1954

Type-species.-Cythereis garretti Howe and McGuirt, 1935 (= Echinocythereis margaritifera (Brady, 1840)).

Echinocythereis clarkana (Ulrich and Bassler, 1804) Plate 4, figure 5

Cythere clarkana Ulrich and Bassler, 1904, p. 98, pl. 35, figs. 1-3, 5, 7-10.

Not Cythere clarkana Ulrich and Bassler, 1904, p. 98, pl. 35, figs. 4, 6 (= Echinocythereis miniscula (Ulrich and Bassler, 1904)).

?Leguminocythereis? clarkana (Ulrich and Bassler). Swain, 1951, p. 43, pl. 6, fig. 18.

Not Trachyleberis clarkana (Ulrich and Bassler). Malkin, 1953, p. 792, pl. 82, figs. 1-3 (= Echinocythereis planibasalis (Ulrich and Bassler, 1904)).

Not Echinocythereis? clarkana (Ulrich and Bassler). Swain, 1974, p. 32 , pl. 5, figs. $13-15$ (figs. $13,14=$ juvenile Murrayina macleani Swain, 1974; fig. $15=$ Echinocythereis planibasalis (Ulrich and Bassler, 1904)).

Diagnosis.-Large size; valve outline, quadrate; prominent reticulum with small spines along the murae; greatest length is midvalve; greatest height is anterior to the central muscle field.

Lectotype. - A male left valve (Ulrich and Bassler, 1904, pl. 35, fig. 5), USNM 35413 a, from the Calvert
Formation, Plum Point, Md., is selected as the lectotype.

Measurement.-The lectotype is $1,200 \mu \mathrm{m}$ in length and $640 \mu \mathrm{m}$ in height.

Occurrence.-Echinocythereis clarkana occurs in the Calvert Formation, below bed 12.

Stratigraphic range.-Upper Oligocene to lower Miocene.

Echinocythereis miniscula (Ulrich and Bassler, 1804)

Plate 4, figure 8

Cythere clarkana var. miniscula Ulrich and Bassler, 1904, p. 99, pl. 35, figs. 11-14.

Cythere clarkana Ulrich and Bassler, 1904, partim, p. 98, pl. 35, figs. 4,6 .

Diagnosis.-Small; valve outline quadrate to ovate; greatest length just ventral of midvalve; greatest height anterior of central muscle scar field; prominent reticulum (with generally thicker murae than $E$. clarkana) with spinelets along the murae.

Lectotype. - A female left valve (Ulrich and Bassler, 1904, pl. 35, fig. 14), USNM 35414 a, from the Calvert Formation at Plum Point, Md., is selected as the lectotype.

Measurements. - The lectotype is $900 \mu \mathrm{m}$ in length and $550 \mu \mathrm{m}$ in height.

Remarks. - Ulrich and Bassler, 1904, designated $E$. miniscula as a variety of $E$. clarkana, because of its smaller size. The syntype suite of $E$. miniscula contains three juvenile and one adult valves. Presumably Ulrich and Bassler's concept of $E$. miniscula was based primarily upon the three juveniles; however, the specimen they illustrated on plate 35 , figure 14 is an adult female left valve. Material collected from various Calvert localities reveals that there is a polymodal distribution in size of Echinocythereis populations. One female mode is centered around about $937 \mu \mathrm{m}$ in length; the adult female selected as the lectotype of $E$. miniscula falls in this class. A second female mode is centered around $1,025 \mu \mathrm{m}$ in length, while the two male modes are centered around $1,062 \mu \mathrm{m}$ and $1,225 \mu \mathrm{m}$ in length. I have interpreted the smaller male and female modes as being $E$. miniscula and the larger two male and female modes as being $E$. clarkana. At present, size appears to be the only means of consistently distinguishing the two forms from each other. The two size groupings may represent two closely related species differing primarily in size, or they may be the same species exhibiting two sizes. The latter might result from seasonal breeding, wherein one size represents fall-winter population and the other a spring-summer population. Males and females of $E$. clarkana and $E$. miniscula occur commonly in the same samples, and both have the same stratigraphic range. 
It is impossible to be certain whether or not there is one or two species in this case; I have elected to conserve both names and recognize two species at this time.

Occurrence.-Echinocythereis miniscula (Ulrich and Bassler, 1904) occurs in the pre-"zone" 12 units of the Calvert Formation in our collections.

Stratigraphic range.-Lower Miocene.

Echinocythereis planibasalis (Ulrich and Bassler, 1904)

Plate 4, figure 7

Cythere planibasalis Ulrich and Bassler, 1904, p. 99, pl. 38, figs. 1-3.

Buntonia? planibasalis (Ulrich and Bassler). Swain, 1951, p. 39, pl. 3, figs. $4,5$.

Trachyleberis clarkana (Ulrich and Bassler). Malkin, 1953, p. 792, pl. 82, figs. 1-3.

Echinocythereis clarkana (Ulrich and Bassler). McLean, 1957, p. 84, pl. 10, figs. 3a-c.

Echinocythereis planibasalis (Ulrich and Bassler). Hazel, 1967, p. 37 , pl. 6 , figs. $4,5,8$.

Echinocythereis? clarkana (Ulrich and Bassler). Swain, 1974, p. 32, pl. 5 , fig. 15 .

Not Echinocythereis? clarkana (Ulrich and Bassler). Swain, 1974, p. 32, pl. 5, figs. 13, 14 (= juvenile Murrayina macleani Swain, 1974).

Diagnosis. - Valve outline ovoid; massive reticulum; greatest length about midvalve; greatest height just anterior of central muscle scar field; prominent ventral carinae with numerous stubby spines on the males.

Measurements. - The holotype, a male right valve, USNM 35428 , is $1,020 \mu \mathrm{m}$ in length and $570 \mu \mathrm{m}$ in height.

Remarks. - Echinocythereis planibasalis (Ulrich and Bassler, 1904) was originally described from the Yorktown Formation. In the present collections I have assigned individuals from the Calvert, Choptank, and Eastover Formations to E. planibasalis. The Miocene forms (particularly those from the Calvert Formation) are somewhat smaller than their Pliocene and younger counterparts; Miocene males, for example, will usually fall in the 950 to $1,000 \mu \mathrm{m}$ length size class. There does appear to be a general size increase through time. Other than size, however, the Miocene individuals seem nearly identical with the Pliocene and younger forms.

The males of $E$. planibasalis have a characteristic ventral rib with numerous blunt spines that is lacking in the females. The females often have a "braided" sequence of murae in the same area of the valve.

Occurrence.-Ulrich and Bassler (1904) found this species in the Yorktown Formation. I have found this species in the Calvert, Choptank, and Eastover (unit C) Formations. Hazel (1967) and Valentine (1971) report this species from modern sediments.

Stratigraphic range. - Lower Miocene to Holocene.

\section{Tribe CYTHERETTINI Triebel, 1952 Genus Pseudocytheretta Cushman, 1906}

Type-species. -Pseudocytheretta edwardsi Cushman, 1906.

Pseudocytheretta burnsi (Ulrich and Bassler, 1804)

Plate 4, figure 6; Plate 5, figures 2, 3, 6, 7, 8 .

Cythere burnsi Ulrich and Bassler, 1904, p. 103, pl. 36, figs. 35-39. Not Cythere burnsi Ulrich and Bassler, 1904, p. 105, pl. 38, fig. 34 (=Pseudocytheretta n. sp.).

Cythere paucipunctata Ulrich and Bassler, 1904, p. 105, pl. 38, figs. 7-9.

Cythere nitidula Ulrich and Bassler, 1904, p. 107, pl. 36, figs. 21-23.

Cythere nitidula var. calvertensis Ulrich and Bassler, 1904, p. 108, pl. 36, fig. 24.

Cythere toumeyi Ulrich and Bassler, 1904, p. 105, pl. 38, figs. 5, 6. Cytheretta burnsi (Ulrich and Bassler). Howe and others, 1935, p. 33, pl. 2, figs. 12-14, 17, 20; pl. 4, figs. 14, 21 ; Malkin, 1953, p. 789, pl. 81, figs. 7, 8, 10, 11; Puri, 1954, p. 282, pl. 7, figs. 1, 2.

Diagnosis.-Extreme asymmetry between the valves; small "tab" like extension of the valve margin in the posterodorsal corner of the left valve; fine to coarse punctation posterior of the central muscle scar field that is ovate in outline; greatest length along the medial portion of the valve.

Lectotype.-A male left valve (Ulrich and Bassler, 1904, pl. 36, fig. 37 (?)), USNM 35411 a, from the Calvert Formation at Plum Point, Md., is selected as the lectotype (pl. 4, fig. 6).

Measurements. -The lectotype is $1,130 \mu \mathrm{m}$ in length and $570 \mu \mathrm{m}$ in height.

Remarks.-Pseudocytheretta burnsi has a complicated nomenclatural history. Like other species of the genus, $P$. burnsi exhibits extreme asymmetry between the valves (compare pl. 4, fig. 6 with pl. 5, fig. 3). This feature, coupled with strong sexual dimorphism and normal individual variation in size, results in populations of valves represented by numerous sizes and shapes. These factors are compounded when the instar sequence is considered. Ulrich and Bassler (1904) did not recognize these features and proposed several species based on juveniles as well as one based on an adult (P. paucipunctata). Pseudocytheretta paucipunctata (Ulrich and Bassler) differs from $P$. burnsi primarily in the nature of the punctae; $P$. paucipunctata has a large ovate punctae as opposed to small fine punctae.

The holotype, USNM 35427, of Pseudocytheretta paucipunctata (Ulrich \& Bassler, 1904) is illustrated in plate 5 , figure 6 . This specimen is a female left valve that is $1,050 \mu \mathrm{m}$ in length and $580 \mu \mathrm{m}$ in height. The remaining species herein synonymized under Pseudocytheretta burnsi (Ulrich and Bassler, 1904) are all juveniles. A left valve, which is probably the specimen illustrated by Ulrich and Bassler (1904) in plate 36, figure 21 , is herein designated the lectotype of 
Pseudocytheretta nitidula (Ulrich and Bassler, 1904). This specimen, USNM 35425 a, was collected from the Plum Point locality of Ulrich and Bassler (1904), in the Calvert Formation. It is illustrated in plate 5, figure 2 and is $860 \mu \mathrm{m}$ in length and $460 \mu \mathrm{m}$ in height.

A left valve (Ulrich and Bassler, 1904, pl. 36, fig. 24), USNM 35426 a, from the Calvert Formation at Plum Point, Md., is selected as the lectotype of Pseudocytheretta calvertensis (Ulrich and Bassler, 1904). The lectotype (pl. 5, fig. 8) is $780 \mu \mathrm{m}$ in length and $410 \mu \mathrm{m}$ in height. The lectotype is one of two specimens in the syntype suite; the other (Ulrich and Bassler, 1904, pl. 36, fig. 25) is a juvenile of Pseudocytheretta plebeia (Ulrich and Bassler, 1904).

A right valve (Ulrich and Bassler, 1904, pl. 38, fig. 5), USNM 35440, from the Peachblossom Creek locality in the Choptank Formation, is selected as the lectotype of Pseudocytheretta toumeyi (Ulrich and Bassler, 1904). The lectotype (pl. 5, fig. 7) is $600 \mu \mathrm{m}$ in length and $320 \mu \mathrm{m}$ in height. The $P$. toumeyi syntype suite originally contained juveniles of two species of Pseudocytheretta. One of the species is from the Yorktown Formation and the other is from the Choptank Formation. The specimen from the Yorktown Formation is lost and was probably conspecific with Pseudocytheretta burnsi sensu McLean (1957), Swain (1974), and Hazel (1971). However, the Yorktown species does not appear to be conspecific with $P$. burnsi (Ulrich and Bassler, 1904), as noted above.

Pseudocytheretta burnsi is known from the Calvert, Choptank, and St. Marys (units A and B) Formations. I do not believe that the specimens reported from the Pliocene (Swain, 1974) are conspecific with $P$. burnsi. The younger forms possess a punctation that covers the whole valve and are much more equivalved (and thus more symmetrical) than $P$. burnsi.

Occurrence.-Pseudocytheretta burnsi (Ulrich and Bassler, 1904) occurs in the Calvert, Choptank, and St. Marys (units A and B) Formations in my collections. Stratigraphic range.-Lower to middle Miocene.

Pseudocytheretta plebeia (Ulrich and Bassler, 1904)

Plate 5, figures 1, 4, 5; Plate 6, figures 5, 6, 7

Cythere plebeia Ulrich and Bassler, 1904, p. 102, pl. 35, figs. 20-29.

Cythere plebeia var. capax Ulrich and Bassler, 1904, p. 103, pl. 35, figs. 30-33.

Cythere plebeia var. modica Ulrich and Bassler, 1904, p. 103, pl. 35, figs. 18, 19.

Cytheridea? chesapeakensis Ulrich and Bassler, 1904, p. 125, pl. 37, fig. 9.

Cythere porcella Ulrich and Bassler, 1904, p. 106, pl. 36, figs. 26-33.

Not Cytheretta porcella (Ulrich and Bassler). Swain, 1951, p. 45, pl. 4, fig. 7; Swain, 1974, p. 24, pl. 2, figs. 19, 20.

Not Cytheretta? sp. aff. C. plebeia (Ulrich and Bassler). Swain, 1951, p. 45, pl. 6, fig. 17. (= Pseudocytheretta n. sp.)

Cytheretta paucipunctata (Ulrich and Bassler). Puri, 1952, p. 204, pl. 39, figs. 1, 2, text figs. 3,4 .
Not Cytheretta ulrichi Puri, 1952, p. 204, pl. 39, fig. 3, text figs. 5-7 (= Pseudocytheretta burnsi (Ulrich and Bassler, 1904)); McLean, 1957, p. 92, pl. 12, figs. 3a-d.

Cytheretta plebia (Ulrich and Bassler). Malkin, 1953, p. 790, pl. 81, figs. 1-6, 9 .

Diagnosis. - Valves asymmetrical; left valve ovoid in outline; right valve with a medial portion of the valve overhanging the ventral margin; dorsal margin of right valve arched; the few punctae are generally circular in outline.

Lectotype. A male left valve (Ulrich and Bassler, 1904, pl. 35), USNM 35429 a, from the Calvert Formation at Plum Point, Md., is selected as the lectotype.

Measurement.-The lectotype (pl. 5, fig. 4) is $1,025 \mu \mathrm{m}$ in length and $550 \mu \mathrm{m}$ in height.

Remarks.-Pseudocytheretta plebeia (Ulrich and Bassler, 1904), like $P$. burnsi, has a complicated nomenclatural history. Puri (1952) pointed out that Cythere (Bairdia) plebeia was used in 1859 by Jones and proposed the new name Cytheretta ulrichi for $P$. plebeia. Puri (1954) later realized that the name Pseudocytheretta porcella (Ulrich and Bassler, 1904) was available and advised that his name $P$. ulrichi be dropped. Swain (1974) followed this suggestion and used $P$. porcella for a species of Pseudocytheretta from the Yorktown Formation. Sohn (1960) has provided the nomenclatural history of Bairdia plebeia, which was originally described by Reuss (1854) and subsequently transferred to Cythere (Bairdia) plebeia by Jones (1859). Vine (1884) transferred the species from the genus Cythere back to the genus Bairdia. Therefore, Cythere plebeia (Ulrich and Bassler, 1904) is not a homonym of Cythere (Bairdia) plebeia, and the trivial name is valid.

Ulrich and Bassler (1904) described two variants of $P$. plebeia and two juvenile species that are all synonymous with $P$. plebeia. The species ascribed to $P$. porcella by Swain (1974) differs from $P$. plebeia by having greater valve symmetry in the right valve.

A right valve, which is probably the specimen illustrated by Ulrich and Bassler, 1904, pl. 35, fig. 32, USNM 35430 a, from the Plum Point locality (Ulrich and Bassler, 1904) of the Calvert Formation is designated as the lectotype of Pseudocytheretta capax (Ulrich and Bassler, 1904). The lectotype (pl. 5, fig. 5) is $990 \mu \mathrm{m}$ in length and $530 \mu \mathrm{m}$ in height. As noted by Ulrich and Bassler (1904) this form is a variety of $P$. plebeia, although in my opinion it may be more of a preservational variant than a biologic one.

A left valve (Ulrich and Bassler, 1904, pl. 35, fig. 18), USNM 35431 a, from the Calvert Formation at Plum Point, MD., is selected as the lectotype of Pseudocytheretta modica (Ulrich and Bassler, 1904). The lectotype (pl. 6, fig. 5) is $900 \mu \mathrm{m}$ in length and $500 \mu \mathrm{m}$ in height and is a typical specimen of $P$. plebeia. The 
distinctions made by Ulrich and Bassler, based on ornamentation or valve shape, are gradational within the population of $P$. plebeia. The remark made by Ulrich and Bassler, about having only left valves of $P$. modica, is curious because one of their syntype specimens is a carapace.

Cytheridea? chesapeakensis Ulrich and Bassler, 1904 , is a well-preserved, very ornate, juvenile of Pseudocytheretta plebeia (Ulrich and Bassler). The holotype, USNM 35444 , is $770 \mu \mathrm{m}$ in length and $410 \mu \mathrm{m}$ in height and is illustrated in pl. 6, fig. 7 .

A left valve (Ulrich and Bassler, 1904, pl. 36, fig. 27), USNM 35432 a, from the Calvert Formation at Plum Point, Md., is selected as the lectotype of Pseudocytheretta porcella (Ulrich and Bassler, 1904). The lectotype (pl. 6, fig. 6) is $770 \mu \mathrm{m}$ in length and $420 \mu \mathrm{m}$ in height. $P$. porcella is a poorly preserved, weakly ornamented juvenile of $P$. plebeia (Ulrich and Bassler, 1904).

Occurrence.-Pseudocytheretta plebeia occurs throughout the Calvert Formation in our collections.

Stratigraphic range. - Lower to middle Miocene.

Genus Protocytheretta Puri, 1958

Type-species.-Cythere daniana Brady, 1869.

Protocytheretta inaequivalvis (Ulrich and Bassler, 1904)

Plate 6, figure 8

Cythere inaequivalvis Ulrich and Bassler, 1904, p. 101, pl. 35, figs. 15, 16.

Not Cythere inaequivalvis Ulrich and Bassler, 1904, p. 101, pl. 35, fig. 17 (= Pseudocytheretta burnsi (Ulrich and Bassler, 1904)).

?Cytheretta inaequivalvis (Ulrich and Bassler). Puri, 1954, p. 284, pl. 8, fig. 9.

Diagnosis.-Strong valve asymmetry; prominent sinuous ventral margin; distinct caudal process; two prominent carinae, one paralleling the dorsal margin and the other running anterior-posterior through the medial part of the valve.

Lectotype.-A right valve (Ulrich and Bassler, 1904, pl. 35, fig. 16), USNM 35421 a, from the Calvert Formation at Plum Point, Md., is selected as the lectotype (pl. 6, fig. 8).

Measurements. - The lectotype is $1,125 \mu \mathrm{m}$ in length and $480 \mu \mathrm{m}$ in height.

Remarks.-Protocytheretta inaequivalvis is extremely rare in the Chesapeake Group sediments. The only known specimens are those illustrated by Ulrich and Bassler (1904).

Occurrence.-Protocytheretta inaequivalvis was reported from the Calvert Formation by Ulrich and Bassler (1904) at their Plum Point locality. It does not occur in our collections.

Stratigraphic range.-Lower Miocene.

\section{Family HEMICYTHERIDAE Puri, 1953 \\ Subfamily HEMICYTHERINAE Puri, 1953 \\ Tribe AURILINI Puri, 1973}

Genus Otikocythere New Genus

Type-species.-Cythere punctistriata Ulrich and Bassler, 1904.

Etymology.-Otikos (Greek), of ears, in reference to the somewhat ear-shaped outline.

Diagnosis.-Low height to length ratio; valves compressed; anterior margin rounded; prominent caudal process; valve surface smooth to reticulate; holamphidont hinge; central muscle scar pattern with three frontal scars linearly arranged, split dorsal and dorsomedian adductor scars and two complete (unsplit) ventral and ventromedian adductor scars.

Comparisons.-Otikocythere is very similar to both Aurila and Heterocythereis, undoubtedly reflecting their close relationship. Otikocythere differs from Heterocythereis in possessing a prominent caudal process and in having an aurilid-shaped right valve. Otikocythere differs from Aurila in having an unsplit ventromedial adductor muscle scar and a "cauditid"shaped left valve.

Remarks. - Three species can be presently assigned to Otikocythere with confidence; they are Cythere punctistriata Ulrich and Bassler, 1904, Hemicythere dalli Howe and Brown, 1935, and Hemicythere redbayensis Howe and Brown, 1935. These taxa all occur in Miocene sediments in the Atlantic Coastal Plain or Florida. Aurila petricola Hartmann, 1974, described from the southwestern coast of Africa, may also belong to Otikocythere, despite its disjunct geographic and temporal position from the other species. However, I have not examined specimens of that species.

Stratigraphic range.-Lower to upper Miocene; Holocene(?).

Otikocythere punctistriata (Ulrich and Bassler, 1804)

Plate 6, figures 1-4; Plate 7, figure 5

Cythere punctistriata Ulrich and Bassler, 1904, p. 108, pl. 38, figs. 22-24.

Cythere francisca Ulrich and Bassler, 1904, p. 110, pl. 38, figs. 19, 20.

Hemicythere punctistriata (Ulrich and Bassler). Malkin, 1953, p. 796, pl. 82, fig. 15 .

Diagnosis.-Large; reticulum weakly to strongly developed in the medial to posterior portion of the valve; greatest length ventral of valve midline; greatest height at anterior cardinal angle; crescent shape of a medioanterior depression on the valve.

Paratype.-A female left valve (Ulrich and Bassler, 1904, pl. 38, fig. 24), USNM 35435, from the Calvert 
Formation at Church Hill, Md., is illustrated (pl. 6, fig. 3 ), being the only whole specimen remaining in the type suite. The holotype, USNM 35434 , is partially destroyed, with only the anterior and posterior part of the valve remaining.

Measurements. - The paratype is $600 \mu \mathrm{m}$ in length and $310 \mu \mathrm{m}$ in height.

Remarks. - Ulrich and Bassler (1904) designated a specimen of $O$. punctistriata from their Peachblossom Creek locality in the Choptank Formation as the holotype. Otikocythere punctistriata occurs abundantly in some parts of the Choptank Formation, but rarely throughout the formation as a whole. Based upon the study collections, the Choptank specimens always are typified by the specimens illustrated on pl. 6, figs. 1, 2, 4 (USNM 256029, 256030, 256031). The Choptank form, however, appears to represent an end member of a morphologic cline starting in the Calvert Formation.

Otikocythere punctistriata is currently known from two localities in the Calvert Formation: (1) from the Ulrich and Bassler locality at Church Hill, Md., and (2) from well cuttings near Denton, Md. Specimens from the latter locality exhibit a continuous gradation from a completely smooth form (similar to the slightly larger O. dalli (Howe and Brown)) to an ornate version represented by the specimen illustrated on pl. 6, fig. 3 (the paratype). Each step of this gradation basically involves the addition of more reticulae starting in the posterior of the valve and progressing toward the anterior. The only morphologic gap occurs between specimens from the upper Calvert Formation and the lower Choptank Formation, as illustrated on pl. 6 (compare figs. 3 and 4). I currently regard the entire sequence as a gradually changing population of a single species (including specimens from both the Calvert and Choptank Formations).

The smooth specimens of Otikocythere punctistriata from the well cuttings near Denton, Md., are quite similar to $O$. dalli (Howe and Brown), differing from $O$. dalli primarily in its slightly smaller size. Howe and Brown (in Howe and graduate students, 1935) noted that their $\boldsymbol{H}$. dalli varies morphologically from a smooth version to a slightly ornate version, where their more ornate ribbed specimens are regarded as a separate species, $O$. redbayensis. The size differences do not appear to be significant and may simply represent geographic variation. Thus $O$. dalli (Howe and Brown) may be a junior synonym of $O$. punctistriata (Ulrich and Bassler).

Otikocythere punctistriata differs from $O$. redbayensis (Howe and Brown) in its larger size, somewhat different shape and in details of the ornament. $O$. redbayensis occurs in upper Miocene sediments in Florida (Red Bay Formation of Puri and Vernon, 1964) and in the eastern shore of Chesapeake Bay.

Otikocythere punctistriata generally occurs abundantly along the present edges of the depositional basins for the Choptank and Calvert Formations. It appears to become very rare to nonexistent towards the center of those basins. Thus, I would surmise that $O$. punctistriata favors shallow marine to possibly polyhaline conditions. Aurila petricola Hartmann, 1974 was also collected from a near shore locality.

Ulrich and Bassler (1904) proposed Cythere francisca based upon a single specimen, USNM 35420, the holotype. This specimen has been lost; however, from Ulrich and Bassler's (1904) description, illustrations, and locality data, this species seems to be a juvenile of Otikocythere punctistriata (Ulrich and Bassler, 1904). A juvenile of $O$. punctistriata from the Choptank Formation at Peachblossom Creek, is illustrated (pl. 7, fig. 5, USNM 256032) for comparison purposes.

Occurrence.-Otikocythere punctistriata occurs in the Calvert and Choptank Formations.

Stratigraphic range-Lower to middle Miocene.

Subfamily THAEROCYTHERINAE Hazel, 1967

Tribe THAFROCYTHERINI Hazel, 1967

Genus Thaerocythere Hazel, 1867

Type-species. -Cythereis crenulata Sars, 1865.

Thaerocythere schmidtae (Malkin, 1953)

Plate 7, figure 8

Trachyleberis? cf. T.? reesidei (Swain). Swain, 1951, p. 30, pl. 3, fig. 13.

Hemicythere schmidtae Malkin, 1953, p. 796, pl. 82, figs. 19-23. Hemicythere schmidtae Malkin. McLean, 1957, p. 92, pl. 12, figs. 2a-d.

Thaerocythere schmidtae (Malkin). Swain, 1974, p. 40, pl. 6, fig. 19; pl. 7, figs. 9-15; pl. 9, figs. 1a-d.

Lectotype.-A female left valve (Malkin, 1953, pl. 82, fig. 2), USNM 256033, from the Yorktown Formation (locality VA-9 of Malkin (1953)), is selected as the lectotype (pl. 7, fig. 8).

Measurements. - The lectotype is $700 \mu \mathrm{m}$ in length and $410 \mu \mathrm{m}$ in height.

Remarks. -Thaerocythere schmidtae occurs frequently in upper Miocene (Eastover Formation, units $\mathrm{C}$ and D), Pliocene, and lower Pleistocene sediments in North Carolina, Virginia, and Maryland, but it has not been found in equivalent age sediments in Florida. On this basis it would appear to be a temperate species, as is the type, Thaerocythere crenulata (Sars, 1865) (see Hazel, 1967). Hazel (1977; in press) illustrated and discussed this taxon. 
Occurrence.-Thaerocythere schmidtae occurs in the Eastover (units $\mathrm{C}$ and D) and Yorktown Formations in my collections.

Stratigraphic range-Upper Miocene to lower Pleistocene.

\section{Genus Puriana Coryell and Fields, 1937}

Type-species. -Favella puella Coryell and Fields, 1937 (= Puriana rugipunctata var. gatunensis Coryell and Fields, 1937).

\section{Puriana rugipunctata (Ulrich and Bassler, 1904)}

Cythere rugipunctata Ulrich and Bassler, 1904, p. 118, pl. 38, figs. $16,17$.

Cythereis rugipunctata (Ulrich and Bassler). Howe and others, 1935 , p. 23, pl. 1, figs. 18, 20-22; pl. 4, figs. $22,23$.

Trachylebereis? rugipunctata (Ulrich and Bassler). Swain, 1951, p. 38 , pl. 6 , fig. 8 .

Favella rugipunctata (Ulrich and Bassler). Malkin, 1953, p. 797, pl. 82, fig. 24.

Puriana rugipunctata (Ulrich and Bassler). McLean, 1957, p. 89, pl. 11, figs. 5a-d.

?Puriana rugipunctata (Ulrich and Bassler). Swain, 1968, p. 18, pl. 5, figs. 8a-c; pl. 7, fig. 4; text figs. 16, 17 .

Puriana rugipunctata (Ulrich and Bassler). Swain, 1974, p. 41, pl. 7, figs. 19, 20.

Remarks. -The holotype of $P$. rugipunctata (Ulrich and Bassler, 1904), USNM 35436, has been crushed and most of the fragments are lost. At present, only two small fragments of the holotype are left. Hazel (1977; in press) has illustrated this species and discusses some of the problems associated with it.

Occurrence.-Puriana rugipunctata occurs in the Eastover (units $\mathrm{C}$ and $\mathrm{D}$ ) Formation, and is common in Pliocene to Holocene deposits along the Atlantic Coast.

Stratigraphic range.-Upper Miocene to Holocene.

Subfamily COQUIMBINAE Ohmert, 1968

Genus Muellerina Bassiouni, 1965

Type-species.-Cythere latimarginata Speyer, 1863.

Muellerina lienenklausi (Ulrich and Bassler, 1904)

Plate 7, figure 4

Cythere lienenklausi Ulrich and Bassler, 1904, p. 114, pl. 38, fig. 31. Not Orionina lienenklausi (Ulrich and Bassler). Puri, 1954, p. 254, pl. 12, fig. 14; text fig. $8 \mathrm{~d}$ (= Neocaudites sp.).

Not Muellerina lienenklausi (Ulrich and Bassler). Swain, 1968, p. 16 , pl. 3 , figs. $2 a-h, 3 a-b, 4 a-b$; text fig. 15 (= Muellerina spp.).

Not Muellerina micula (Ulrich and Bassler). Swain, 1974, p. 38, pl. 7, figs, 1-8 (= Muellerina spp.).

Diagnosis.-Small; rectangular valve outline; welldeveloped reticulum; details of fossae arrangement characteristic, such as the anterior-most (ventral to dorsal) row of fossae consisting of two small rounded fossae, one dorsal to the other, followed dorsally by two other rounded fossae, one anterior to the other; these in turn are followed dorsally by two more fossae, with one fossa dorsal to the other and sometimes fused to form one elongate fossa; prominent carina extends subparallel to the valve margin, originating at the anterodorsal corner and proceeding to the posterodorsal corner. These carina become slightly broader just posterior of the ventral concavity and contain five to six small fossae (relationship of these fossae to one another are characteristic); the carina splits and encircles several more fossae in the posteroventral region of the valve.

Measurements.-The holotype, USNM 35422, from the Calvert Formation at Plum Point, Md., is $590 \mu \mathrm{m}$ in length and $290 \mu \mathrm{m}$ in height. The illustrated specimen, a female right valve, USNM 256034, from the type locality, is $620 \mu \mathrm{m}$ in length and $330 \mu \mathrm{m}$ in height.

Remarks. - The holotype, a male left valve, is crushed. However, the specimen is still sufficiently intact to use it as a means of recognizing complete specimens from the type locality at Plum Point, bed 10, of the Calvert Formation. There are only two species of Muellerina known from Bed 10. One of these species appears to be the adult of Cythere micula Ulrich and Bassler, 1904 and is illustrated on pl. 7, fig. 2. The other species is morphologically identical with the holotype of $M$. lienenklausi. The two species are easily distinguished from one another by several characteristics, such as arrangement of the anterior-most row of fossae, where $M$. micula has a row of several circular fossae, one dorsal to the other.

Hazel (1967) discusses the nomenclatural confusion associated with various Neogene species of Muellerina. Most of these species of Muellerina have been identified as Murrayina martini (Ulrich and Bassler, 1904), even though Murrayina and Muellerina are in different families. Hazel (1967) argued that what was identified as Murrayina martini by many authors should be referred to Muellerina lienenklausi. Subsequently, Hazel (in press) and the author (in studies in progress) have recognized numerous species of Muellerina in the Chesapeake Group sediments. Thus, what at one time was regarded as a single species is now believed to be several. Swain (1974) also discusses this problem and argues that the holotype of Muellerina lienenklausi is too badly damaged to be recognized. He believes that the juveniles in the $M$. micula syntype collection are more representative of what was referred to in the past as Murrayina martini. In my opinion, most of the Muellerina species referred to Murrayina martini by various authors are conspecific with Muellerina species from post-Miocene deposits. The Muellerina micula 
syntype slide contains two species of Muellerina, a juvenile of $M$. lienenklausi (Ulrich and Bassler, 1904), and the specimen selected as the lectotype of $M$. micula (Ulrich and Bassler, 1904). The latter specimen is believed to be the juvenile of the specimen illustrated on plate 7, figure 2. Many of the specimens illustrated by Swain $(1968 ; 1974)$ as Muellerina micula and Muellerina lienenklausi are $M$. ohmerti Hazel, 1977.

The majority of Muellerina species are superficially quite similar to each other. However, each can be readily distinguished by fossae pattern, size, and valve outline. When the fossae patterns of numerous Muellerina species have been studied, distinctive species groups can be recognized, and some of these complexes can be traced from the Calvert Formation at least into the Pliocene.

Occurrence. - I have found Muellerina lienenklausi in bed 10 and older beds within the Calvert Formation.

Stratigraphic range.-Lower Miocene.

Muellerina micula (Ulrich and Bassler, 1904)

Plate 7, figures 2,3

Cythere micula Ulrich and Bassler, 1904, p. 116, pl. 36, figs. 19, 20. Not Cythere micula Ulrich and Bassler, 1904, p. 116, pl. 36, fig. 18 (= Muellerina lienenklausi (Ulrich and Bassler, 1904)).

Trachyleberis martini (Ulrich and Bassler). Malkin, 1953, p. 793, pl. 82, figs. 9, 13.

Not Muellerina micula (Ulrich and Bassler). Swain, 1974, p. 38, pl. 7, figs. 1-8 (= Muellerina spp.).

Diagnosis.-Large; strong reticulum; details of the fossae pattern characteristic, such as a continuous anterior-most row of round fossae subparallel to the anterior margin; murae thin relative to $M$. lienenklausi; ventral carinae are subparallel to ventral margin terminating just posterior of ventral concavity.

Lectotype.-A juvenile left valve illustrated by Ulrich and Bassler, 1904, plate 36, figure 20, USNM 35424 a, from the Calvert Formation at Plum Point, Md., is selected as the lectotype.

Measurements. -The lectotype (pl. 7, fig. 3) is $500 \mu \mathrm{m}$ in length and $270 \mu \mathrm{m}$ in height. The illustrated specimen (pl. 7, fig. 2), a female left valve, USNM 256035, is $640 \mu \mathrm{m}$ in length and $350 \mu \mathrm{m}$ in height.

Remarks.-Muellerina micula was represented by a syntypic suite of three valves. The specimen illustrated on plate 36, figure 19 of Ulrich and Bassler (1904) has been destroyed and lost except for a small fragment. Ulrich and Bassler (1904) note that the specimen illustrated in figure 18 is smaller than normal, suggesting that it was not what they regarded as typical. The latter specimen, in my opinion, is a juvenile of Muellerina lienenklausi, and is not con- specific with the specimen illustrated in figure 20 . The specimen illustrated in figure 20 and chosen here as the lectotype of $M$. micula, appears to be a juvenile conspecific with the specimen illustrated herein on plate 7 , figure 2. The latter specimen is representative of the dominant Muellerina species in the Calvert Formation and is regarded by the author as $M$. micula. The Muellerina micula ornament pattern varies, often due to the merging of two or more fossae or the degree of expression of the carinae. However, this variation never overlaps with the ornamentation pattern seen in $M$. lienenklausi, although the two species are apparently closely related.

There is an undescribed species of Muellerina occurring in the Choptank Formation that is morphologically disjunct from $M$. micula, but very similar to it.

Occurrence. - Ulrich and Bassler (1904) reported this species from the Calvert and Yorktown Formations. The Yorktown occurrence represents another species of Muellerina. Mullereina micula occurs throughout the Calvert Formation in our collections.

Stratigraphic range.-Lower to middle Miocene.

Subfamily ORIONININAE Puri, 1973 Genus Orionina Puri, 1954

Type-species.-Cythere vaughani Ulrich and Bassler, 1904.

Orionina vaughani (Ulrich and Bassler, 1904)

Cythere vaughani Ulrich and Bassler, 1904, p. 109, pl. 38, figs. 25-27.

Cythereis vaughani (Ulrich and Bassler). Howe and others, 1935, p. 25 , pl. 3, figs. 24-26; pl. 4, fig. 13 .

?Trachyleberis vaughani (Ulrich and Basssler). Swain, 1951, p. 37, pl. 6, figs. 6,7 .

Trachyleberis vaughani (Ulrich and Bassler). Malkin, 1953, p. 794, pl. 82, fig. 14 .

Orionina vaughani (Ulrich and Bassler). Puri, 1954, p. 254, pl. 12, fig. 16; McLean, 1957, p. 88, pl. 11, figs. 6a-b; Swain, 1968, p. 21, pl. 4, figs. 4a-e; text fig. 19; Swain, 1974, p. 39, pl. 7, fig. 17; pl. 12 , figs. 2a-h.

Remarks.-Ulrich and Bassler's (1904) holotype, USNM 35442 , the only deposited specimen, is lost. However, Hazel (in press) has recently treated this species and the reader is referred to that study.

Occurrence.-Orionina vaughani occurs commonly in Pliocene to Holocene sediments in the Atlantic coastal plain and Florida.

Stratigraphic range.-Pliocene to Holocene.

Subfamily CAMPYLOCYTHERINAE Puri, 1960

Tribe LEGUMINOCYTHERINI Howe, 1961

Genus Bensonocythere Hazel, 1967

Type-species.-Leguminocythereis whitei Swain, 1951. 
Bensonocythere calverti (Ulrich and Bassler, 1904)

Plate 7, figure 6

Cythere calverti Ulrich and Bassler, 1904, p. 100, pl. 38, figs. 11-13.

Diagnosis. - Large; prominent reticulum; absence of carinae; rectangular valve outline.

Measurements. - The holotype, USNM 35412, from the Calvert Formation at Plum Point, Md., is $800 \mu \mathrm{m}$ in length and $430 \mu \mathrm{m}$ in height.

Remarks.-Bensonocythere calverti is an extremely rare component of the Chesapeake Group sediments. As with several other ostracodes in these sediments, $B$. calverti increases in overall size through time so that the Yorktown Formation individuals are larger but otherwise morphologically similar to those from the Calvert Formation.

Occurrence.-Bensonocythere calverti occurs in the Calvert, Eastover (units C and D), and Yorktown Formations in our collections.

Stratigraphic range--Lower Miocene to Lower Pliocene.

Family PARACYTHERIDEIDAE Puri, 1957

Genus Paracytheridea G. W. Muller, 1894

Type-species.-Paracytheridea depressa G. W. Muller, 1894.

Paracytheridea altila Edwards, 1944

Plate 7, figure 7

Cytheropteron nodosum Ulrich and Bassler, 1904, p. 129, pl. 38, figs. 37-40.

Not Cytheropteron nodosum Brady, 1868, p. 448, pl. 34, figs. 31-34. Paracytheridea nodosum (Ulrich and Bassler). Howe and others, 1935, p. 37, pl. 3, fig. 7; Swain, 1951, p. 51, pl. 3, figs. 19-22.

Paracytheridea altila Edwards, 1944, p. 512, pl. 85, figs. 20, 21; Swain, 1974, p. 20, pl. 1, fig. 17.

Paracytheridea vandenboldi Puri, 1953, p. 751 (new name); Malkin, 1953 , p. 780 , pl. 79, fig. 5; Puri, 1954, p. 238, pl. 3, fig. 7; text figs. 5a, b; McLean, 1957, p. 75, pl. 8, figs. 4a-b.

?Paracytheridea cf. P. vandenboldi Puri. Swain, 1968, p. 11, pl. 2, figs. $4 a, b$.

Measurements. -The holotype (C. nodosum Ulrich and Bassler, 1904), USNM 35443, is $650 \mu \mathrm{m}$ in length and $300 \mu \mathrm{m}$ in height.

Remarks.-Cytheropteron nodosum Ulrich and Bassler, 1904 is a junior homonym of $C$. nodosum Brady, 1868. Puri (1953) recognized this and renamed the species Paracytheridea vandenboldi. However, van den Bold (1968) has shown that P. altila Edwards, 1944 is conspecific with $P$. nodosum (Ulrich and Bassler) and therefore is the valid name for the species.

Occurrence.-Ulrich and Bassler (1904) found this species in the Yorktown Formation (see also Hazel, 1971); Edwards (1944) reported it in the Duplin Marl of
South Carolina. The species occurs in the Eastover (unit C) and Yorktown Formations in our collections. It has also been reported from Pleistocene and modern sediments (Valentine, 1971).

Stratigraphic range.-Upper Miocene to Holocene.

Genus Microcytherura G. W. Mueller, 1894

Type-species.-Microcytherura nigrescens G. W. Muller, 1894.

Microcytherura shattucki (Ulrich and Bassler, 1904)

Plate 7, figure 1

Cythere(?) shattucki Ulrich and Bassler, 1904, p. 121, pl. 38, fig. 10. Not Paracytheridea shattucki (Ulrich and Bassler). Malkin, 1953, p. 780, pl. 79, figs. 6-9. (? = Microcytherura n. sp.)

Not Shattuckocythere shattucki (Ulrich and Bassler). Swain, 1974, p. 21, pl. 1, fig. 14; pl. 8, fig. 9 (? = Microcytherura similis (Malkin, 1953)).

Diagnosis. -Triangular to subtriangular valve shape with a broad anterior and a surface ornamentation consisting of a weak reticulum superimposed on a finely punctate surface; punctae are very numerous and small, densely distributed in each solum.

Measurements. -The illustrated specimen, USNM 256036, (pl. 7, fig. 1) is $600 \mu \mathrm{m}$ in length and $300 \mu \mathrm{m}$ in height.

Remarks.-The anterior half of the holotype of Microcytherura shattucki, USNM 35437, is all that remains intact; the posterior portion of the valve consists of several fragments. The type locality of this species is at Ulrich and Bassler's Paw Paw Point, in the Choptank Formation. Based on our collections, only one species of Microcytherura occurs in the Choptank Formation, and this appears to be conspecific with the holotype. It also conforms to Ulrich and Bassler's description and illustration of $M$. shattucki. The illustrated specimen (pl. 7, fig. 1) comes from bed 17 of the Choptank Formation at Scientist's Cliffs on the Western Shore of Chesapeake Bay.

Swain (1974) selected this species as the type of his genus Shattuckocythere. In my opinion, this species is congeneric with the type species of Microcytherura ( $M$. nigrescens G. W. Mueller, 1894). The diagnostic criteria given by Swain (1974) for Shattuckocythere do not differentiate it from Microcytherura except in the type of hingement, which Swain describes as being antimerodont (Microcytherura being hemimerodont). All of Swain's (1974) Shattuckocythere species have a hemimerodont hinge except for the species Eocytheropteron? yorktownensis Malkin, 1953 which he also places in Shattuckocythere and which has an antimerodont hinge. I do not consider Eocytheropteron? yorktownensis to be a Microcytherura. 
Occurrence.-Microcytherura shattucki occurs only in the Choptank Formation in our collections.

Stratigraphic range.-Middle Miocene.

Microcytherura curta (Malkin, 1953)

Plate 7, figure 10

Paracytheridea shattucki curta Malkin, 1953, p. 791, pl. 79, figs. 10-12.

Diagnosis. -Trapezoidal right valve in the female, subtrapezoidal left valve in the female, and both valves in the male; a subdued reticulum superimposed over fine punctation that tends to occupy the entire solum.

Lectotype. - A male left valve illustrated by Malkin (1953, pl. 79, fig. 11), USNM 256037, from the Yorktown Formation (Malkin, 1953, locality VA-10) is selected as the lectotype.

Measurements.-The lectotype (pl. 7, fig. 10) is $600 \mu \mathrm{m}$ in length and $300 \mu \mathrm{m}$ in height.

Remarks. - Malkin (1953) originally proposed Microcytherura curta as a subspecies of $M$. shattucki. However, $M$. curta differs from $M$. shattucki in having fewer and larger punctae and a different valve outline. Further, the two species are not known from the same or even adjacent stratigraphic horizons. Microcytherura curta, however, does appear to be closely related to $M$. similis, based upon general morphologic similarity.

Occurrence-Microcytherura curta occurs only in the Yorktown Formation in our collections.

Stratigraphic range.-Pliocene.

\section{Microcytherura similis (Malkin, 1953)}

Plate 7, figure 9

Paracytheridea similis Malkin, 1953, p. 781, pl. 79, figs. 13, 14. ?Shattuckocythere similis (Malkin). Swain, 1974, p. 22, pl. 9, fig. 14. Not Shattuckocythere similis (Malkin). Swain, 1974, p. 22, pl. 1, fig. 19a (= Microcytherura curta (Malkin, 1953)).

Shattuckocythere shattucki (Ulrich and Bassler). Swain, 1974, p. 21, pl. 1, fig. 14; pl. 8, fig. 9.

Shattuckocythere yorktownensis (Malkin). Swain, 1974, p. 22, pl. 3, fig. 13; pl. 9, figs. 9a, b.

Diagnosis. -Subtrapezoidal valve outline; subdued reticulum with wide murae; prominent punctae usually located mainly along the edge of the murae in the solum.

Lectotype.-A female right valve illustrated by Malkin (1953, pl. 79, fig. 13), USNM 256038, is selected as the lectotype. This specimen is from the Yorktown Formation (Malkin, 1953, locality VA-10).

Measurements. - The lectotype is $550 \mu \mathrm{m}$ in length and $280 \mu \mathrm{m}$ in height.

Occurrence-Microcytherura similis occurs commonly in the Pliocene and lower Pleistocene formations in the Atlantic Coastal Plain (Hazel, 1977).

Stratigraphic range.-Pliocene to lower Pleistocene.

\section{REFERENCES CITED}

Akers, W. H., 1972, Planktonic foraminifera and biostratigraphy of some Neogene formations, northern Florida and Atlantic Coastal Plain: Tulane Studies in Geology, v. 9, no. 1-4, 139 p.

Berggren, W. A., and Couvering, J. A. Van, 1974, The Late Neogene; Biostratigraphy, geochronology and paleoclimatology of the last 15 million years in marine and continental sequences, in Developments in Palaeontology and Stratigraphy, volume 2: Amsterdam, 216 p. Also available in Palaeogeography, Palaeoclimatology, Palaeoecology, v. 16, no. 1-2.

Blackwelder, B. W., and Ward, L. W., 1976, Stratigraphy of the Chesapeake Group of Maryland and Virginia: Geological Society of America, Northeast-Southeast Joint Meeting, Arlington, Virginia, Guidebook for Field Trip 7b, $55 \mathrm{p}$.

Blow, W. H., 1956, Origin and evolution of the foraminiferal genus Orbulina D'Orbigny: Micropaleontology, v. 2, no. 1, p. 57-70.

1969, Late middle Eocene to Recent planktonic foraminiferal biostratigraphy, in Brönniman, P., and Renz, H. H., eds., Proceedings of the First International Conference on Planktonic Microfossils, Geneva, 1967: Leiden, E. J. Brill, p. 199-421.

Bold, W. A. van den, 1968, Ostracoda of the Yague Group (Neogene) of the northern Dominican Republic: Bulletins of American Paleontology, v. 54, no. 239, p. 5-89.

Brady, G. S., 1868, A monograph of the Recent British Ostracoda: Linnean Society of London Transactions, v. 26, p. 353-395, pls. 23-41.

Clark, W. B., and Miller, B. L., 1906, A brief summary of the geology of the Virginia coastal plain, Part 1 of Ries, Heinrich, A preliminary report on a part of the clays of Virginia: Virginia Geological Survey Bulletin 2, p. 11-24.

Edwards, R. A., 1944, Ostracoda from the Duplin Marl (Upper Miocene) of North Carolina: Journal of Paleontology, v. 18, no. 6, p. 505-528.

Gernant, R. E., 1970, Paleocology of the Choptank Formation (Miocene) of Maryland and Virginia: Maryland Geological Survey Report of Investigations, no. 12, 90 p.

Gibson, T. G., 1971, Miocene of the Middle Atlantic Coastal Plain, in Gernant, R. E., Gibson, T. G., and Whitmore, F. C., Jr., Environmental history of Maryland Miocene: Maryland Geological Survey Guidebook No. 3, p. 1-15.

Hartmann, Gerd, 1974, Die Ostracoden des Untersuchungsgebiets, Part III: Hamburgisches Zoologisches Museum und Institut, v. 69 , p. $229-520$.

Hartmann, Gerd, and Puri, H. S., 1974, Summary of neontological and paleontological classification of Ostracoda: Hamburgisches Zoologisches Museum und Institut, Mitteilungen, v. 70, p. 7-73.

Hazel, J. E., 1967, Classification and distribution of the Recent Hemicytheridae and Trachyleberididae (Ostracoda) off northeastern North America: U.S. Geological Survey Professional Paper 564, 49 p.

1971, Ostracode biostratigraphy of the Yorktown formation (upper Miocene and lower Pliocene) of Virginia and North Carolina: U.S. Geological Survey Professional Paper 704, 13 p.

1977, Distribution of some biostratigraphically diagnostic Ostracodes in the Pliocene and lower Pleistocene of Virginia and northern North Carolina: U.S. Geological Survey Journal of Research, v. 5, no. 3, p. 373-388.

in press, Age and correlation of the Yorktown (Pliocene) and Croatan (Pliocene and Pleistocene) Formations at the Lee Creek, North Carolina, open pit mine: Smithsonian Contributions in Paleobiology. 
Howe, H. V., and graduate students, 1935, Ostracoda of the Arca zone of the Choctawhatchee Miocene of Florida: Florida Department of Conservation Bulletin no. 13, $47 \mathrm{p}$.

Jones, T. R., 1859, Notes on the species of Permian Entomostraca, in Kirkby, J. W., Permian Entomostraca from the shelllimestone of Durham: Newcastle-upon-Tyne, Tyneside Naturalists' Field Club Transactions, v. 4, p. 122-171 (1860).

Malkin, D. S., 1953, Biostratigraphic study of Miocene Ostracoda of New Jersey, Maryland, and Virginia: Journal of Paleontology, v. 27, no. 6, p. 761-799.

McLean, J. D., 1957, The Ostracoda of the Yorktown Formation in the York-James Peninsula of Virginia: Bulletins of American Paleontology, v. 38, no. 167, p. 57-103.

1966, Miocene and Pleistocene Foraminifera and Ostracoda of southeastern Virginia, Part II: Virginia Division of Mineral Resources Report of Investigations, v. 9, $123 \mathrm{p}$.

Morkhoven, F. P. C. M., 1972, Bathymetry of Recent marine Ostracoda in the northwest Gulf of Mexico: Gulf Coast Association of Geological Societies, v. 22, p. 241-251.

Pooser, W. K., 1965, Biostratigraphy of Cenozoic ostracoda from South Carolina, in Arthropoda, University of Kansas Paleontological Contributions, no. 38, Article 8: Lawrence, 80 p.

Puri, H. S., 1952, Ostracode genera Cytheretta and Paracytheretta in America: Journal of Paleontology, v. 26, no. 2, p. 199-212.

1953, Taxonomic comment on "Ostracoda from Wells in North Carolina, Part I-Cenozoic Ostracods” by F. M. Swain: Journal of Paleontology, v. 27, p. 750-752.

1954, Contributions to the study of the Miocene of the Florida panhandle: Florida Department of Conservation Geological Bulletin, v. 36, p. 216-345.

1956, Two new Tertiary Ostracode genera from Florida: Journal of Paleontology, v. 30, no. 2, p. 274-277.

Puri, H. S., and Vernon, R. O., 1964, Summary of the geology of Florida and a guidebook to the classic exposures: Tallahassee, Florida Geological Survey Special Publication no. 5, 312 p.

Reuss, A. E., 1854, Ueber Entomostraceen und Foraminiferen im Zechstein der Wetterau: Jahresbuch Wetterauer Ges. Gesamm. Naturk. Hanau, 1851-1853, p. 59-77.
Sandberg, P. A., 1964, Larvel-adult relationships in some species of the Ostracode genus Haplocytheridea: Micropaleontology, v. 10 , no. 3, p. 357-368.

Shattuck, G. B., 1904, Geological and paleontological relations, with a review of earlier investigations: Maryland Geological Survey, XXXIII-CXXVII, 7 pls.

Sohn, I. G., 1960, Paleozoic species of Bairdia and related genera: U.S. Geological Survey Professional Paper 330-A, p. 1-105.

Swain, F. M., 1948, Cretaceous and Tertiary subsurface geology, in Anderson, J. L., and others, Ostracoda from the Hammond well [Md.]: Maryland Department of Geology, Mines and Water Resources Bulletin 2, p. 187-212.

1951, Ostracoda from wells in North Carolina, Part 1-Cenozoic Ostracoda: U.S. Geological Survey Professional Paper 234-A, 58 p.

1968, Ostracoda from the upper Tertiary Waccamaw Formation of North Carolina and South Carolina: U.S. Geological Survey Professional Paper 573-D, p. D1-D37.

Swain, F. M., 1974, Some Upper Miocene and Pliocene(?) Ostracoda of Atlantic Coastal Region for use in hydrologic studies: U.S. Geological Survey Professional Paper 821, 50 p.

Ulrich, E. O., and Bassler, R. S., 1904, Systematic paleontology, Miocene (Ostracoda): Maryland Geological Survey Miocene Text, p. 98-130.

Valentine, P. C., 1971, Climatic implications of a late Pleistocene ostracode assemblage from southeastern Virginia: U.S. Geological Survey Professional Paper 683-D, 28 p.

Vine, G. R., 1884, Notes on the Carboniferous Entomostraca and Foraminifera of the North Yorkshire shales: Yorkshire Geologic and Polytechnic Society, Proceedings, n.s., 8 (1882-1884), p. 226-239.

Ward, L. W., and Blackwelder, B. W., in press, Stratigraphic revision of Upper Miocene and Lower Pliocene beds of the Chesapeake Group-Middle Atlantic Coastal Plain: Virginia Geological Survey publication. 


\section{INDEX}

[Italic page numbers indicate major references]

A

Page

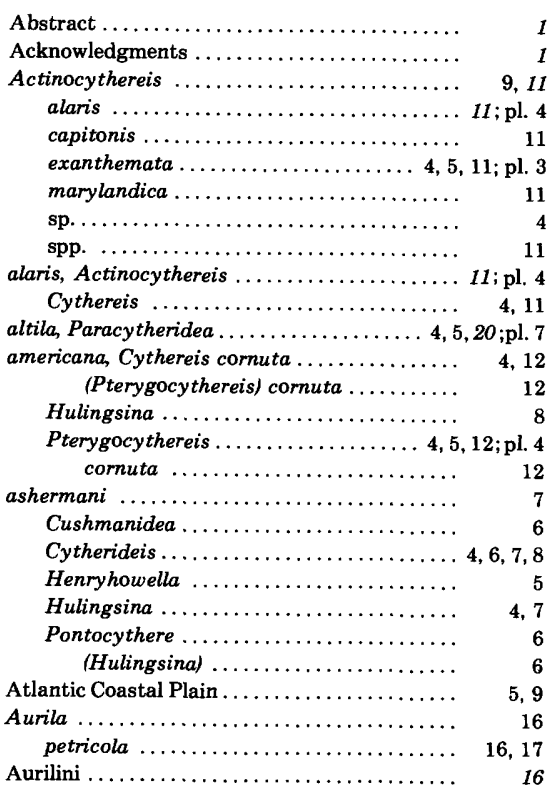

B

Bairdia plebeia ......................... $\quad 15$

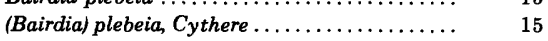

Bensonocythere $\ldots \ldots \ldots \ldots \ldots \ldots \ldots \ldots \ldots, \quad 19$ calverti $\ldots \ldots \ldots \ldots \ldots \ldots \ldots \ldots \ldots, 4,5,20 ; \mathrm{pl}, 7$

bicornis, Cythere dorsicornis .............. 4, 10

Murrayina ...

dorsicornis

blanpedi, Haplocytheridea

Boston Cliffs Member, Chopt

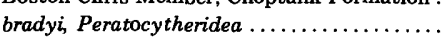

Buntonia planibasalis .

burnsi, Cythere....

Cytheretta $\ldots \ldots \ldots \ldots \ldots \ldots \ldots \ldots \ldots \ldots, \quad 4,14$

Pseudocytheretta....... 4, 5, 14, 15, 16; pls. 4, 5

\section{C}

Calvert Beach Member, Choptank Formation

Calvert Formation ..... 1, 2, 3, 4, 8, 11, 13, 14, 15, 16, 20 calvertensis, Cythere nitidula

Hulingsina. . .

Pseudocytheretta .................... 15; pl. 5

calverti, Bensonocythere ............. 4, 5,20; pl. 7

Cythere

Campylocytherinae

capax, Cythere plebeia

Pseudocytheretto

Cape Hatteras ....

capitonis, Actinocythereis.

Carolinian Faunal Province.

chesapeakensis, Cytheridea

Pseudocytheretta.
Choptank Formation

Formation ................. 1, 2, 4,6,8, 9. 10, 13, 14, 20; pl. 2

Church Hill, Md., Calvert Formation ........ 3; pl. 6 circularis, Praeorbulina glomerosa...

Claremont Manor Member, Eastover Formation ....

clarkana, Cythere...

Leguminocythereis ................. 13

miniscula, Cythere ................. 4, 13

Trachyleberis ...................... 13, 14

Clithrocytheridea diagonalis .............. $\quad 3,4$ virginiensis

Cobham Bay Member, Eastover Formation ...

Conoy Member, Choptank Formation .........

Cooper Formation, S. C.

Coquimbinae ....

americana, Cythereis ............. 4, 12

(Pterygocythereis)

coryelli, Cytherura

crenulata, Cythereis.

Thaerocythere $\ldots \ldots \ldots \ldots \ldots \ldots \ldots \ldots \ldots, 17$

Croatan Formation .

curta, Microcytherura .............. 4, 5, 21; pl. 7

Paracytheridea shattucki ............. 4,21

Cushmanidea ashermani

echolsae.

$$
\text { fabula... }
$$

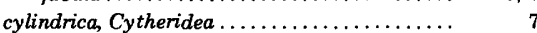

Henryhowella ................... 5

Hulingsina ................... 4, 7; pl. 2

Cythere burnsi ......................... 4, 14

calverti ........................ 4,20

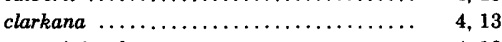

miniscula $\ldots \ldots \ldots \ldots \ldots \ldots \ldots \ldots, 4,13$

daniana ......................... 16

dorsicornis ........................ 4,10

bicornis ....................... 4,10

$\operatorname{evax} \ldots \ldots \ldots \ldots \ldots \ldots \ldots \ldots \ldots \ldots \ldots \ldots \ldots \ldots \ldots \ldots \ldots \ldots \ldots, 4,12$

oblongula $\ldots \ldots \ldots \ldots \ldots \ldots \ldots \ldots, 4,12$

exanthemata ...................... 4, 11

francisca ............................ 4, 16, 17

inaequivalvis ..................... 4,16

$\begin{array}{lr}\text { latimarginata } \ldots \ldots \ldots \ldots \ldots \ldots \ldots \ldots \ldots \ldots \ldots \ldots \ldots \ldots \ldots \ldots & 18 \\ \text { latissima } \ldots \ldots \ldots \ldots \ldots \ldots \ldots \ldots & 9\end{array}$

$\begin{array}{lr}\text { latissima } \ldots \ldots \ldots \ldots \ldots \ldots \ldots \ldots \ldots \ldots & 9 \\ \text { lienenklausi } \ldots \ldots \ldots \ldots \ldots \ldots \ldots \ldots \ldots & 4,18\end{array}$

martini ......................... 4,10

micula ......................... 4, 18, 19

mulleri ............................ 3

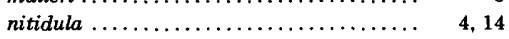

calvertensis $\ldots \ldots \ldots \ldots \ldots \ldots \ldots \ldots, 4,14$

paucipunctata ..................... 4, 14

planibasalis ...................... 4, 14

plebeia .......................... 4, 15

capax $\ldots \ldots \ldots \ldots \ldots \ldots \ldots \ldots \ldots, 4,15$

modica ....................... 4,15

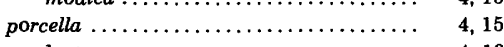

producta ....................... 4, 10

punctistriata .................... 1, 3, 4,16

rugipunctata ..................... 4,18

shattucki $\ldots \ldots \ldots \ldots \ldots \ldots \ldots \ldots \ldots, 4,9,20$

spiniplicata $\ldots \ldots \ldots \ldots \ldots \ldots \ldots \ldots \ldots, 4,12$

subovalis ....................... $4,5,6$

toumeyi ....................... 4,14

vaughani.

(Bairdia) plebeia. $\begin{array}{cc} & \text { Page } \\ \text { Cythereis alaris ...................... } & 4,11\end{array}$

cornuta americana $\ldots \ldots \ldots \ldots \ldots \ldots \ldots \ldots, 4,12$

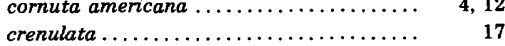

garretti ......................... 13

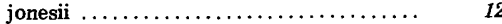

producta ....................... 10

(Pterygocythereis) .................. 12

Cytheretta burnsi ...................... 14

inaequivalvis ..................... 16

paucipunctata ................... 15

plebia $\ldots \ldots \ldots \ldots \ldots \ldots \ldots \ldots \ldots \ldots, \quad 15$

porcella $\ldots \ldots \ldots \ldots \ldots \ldots \ldots \ldots \ldots \ldots, \quad 15$

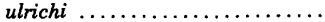

Cytherettini ........................... 14

Cytheridea $\ldots \ldots \ldots \ldots \ldots \ldots \ldots \ldots \ldots \ldots \ldots, \quad 3$

chesapeakensis .................... 4, 15, 16

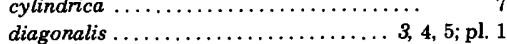

diagonalis $\ldots \ldots \ldots \ldots \ldots \ldots \ldots \ldots \ldots \ldots, 4,4,5 ;$ pl. 1
muelleri $\ldots \ldots \ldots \ldots \ldots \ldots \ldots \ldots \ldots, \ldots \ldots \ldots$

setipunctata.......................

subovalis ...................... 4, 5;pl. 1

subovata ...................... 4,6

virginiensis .................... $3,4,5 ;$ pl. 1

sp................................. 5

Cytherideidae .........................

Cytherideis ashermani ................ 4, 6, 7, 8

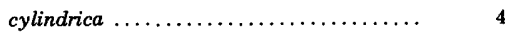

echolsae ........................ 4,7

longula $\ldots \ldots \ldots \ldots \ldots \ldots \ldots \ldots \ldots \ldots, \quad 4,8$

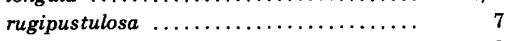

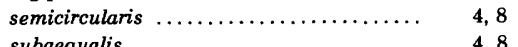

subaequalis ....................

Cytheropteron leonensis ................ 9,9

nodosum ..................... 4, 20; pl. 7

yorktownensis ............. 4, 5, 9; pl. 2

coryelli $\ldots \ldots \ldots \ldots \ldots \ldots \ldots \ldots \ldots \ldots, 4,5,9 ; \mathrm{pl} .2$

coryelli $\ldots \ldots \ldots \ldots \ldots \ldots \ldots \ldots \ldots \ldots \ldots, 4,5,9 ;$ pl. 2
gibba $\ldots \ldots \ldots \ldots \ldots \ldots \ldots \ldots \ldots \ldots$,

Cytheruridae.

Cytherurinae ....

D

dalli, Hemicythere

Otikocythere

daniana, Cythere

ttings ................

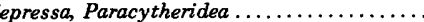

diagonalis, Clithrocytheridea ............... 3,4

Cytheridea ..................... 3, 4,5; pl. 1

Diatomaceous Earth Member, Calvert Forma-

$\begin{aligned} \text { tion } \ldots \ldots \ldots \ldots \ldots \ldots \ldots \ldots \ldots & 2 \\ \text { dorsicornis, } & 2\end{aligned}$

bicornis, Cythere ...................... $\quad 4,10$

Murrayina $\ldots \ldots \ldots \ldots \ldots \ldots \ldots \ldots \ldots \ldots \ldots$ pl. 3

$\begin{array}{lr}\text { Drum Cliff Member, Choptank Formation .... } & 2 \\ \text { Duplin Marl, South Carolina ............... } & 20\end{array}$

\section{E}

Eastover Formation ................. I, 2, 14, 17

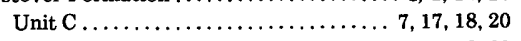
Unit D $\ldots \ldots \ldots \ldots \ldots \ldots \ldots \ldots, 7,13,17,18,20$

$\begin{array}{ll}\text { Echinocythereidini } \ldots \ldots \ldots \ldots \ldots \ldots \ldots \ldots \ldots \ldots \ldots \ldots \ldots \ldots & 13 \\ \text { Echinocythereis } \ldots \ldots \ldots \ldots \ldots \ldots \ldots \ldots & 13\end{array}$ clarkana $\ldots \ldots \ldots \ldots \ldots \ldots \ldots \ldots, 4,5,13,14 ; \mathrm{pl} .4$ 


\begin{tabular}{|c|c|}
\hline Echinocythereis-Continued & Page \\
\hline evax $\ldots \ldots \ldots \ldots \ldots$ & 12 \\
\hline margaritifera . & 13 \\
\hline miniscula.... & \multirow{2}{*}{$\begin{array}{l}4,5,13,14 ; \text { pl. } 4 \\
4,5,13,14 ; \text { pl. } 4\end{array}$} \\
\hline planibasalis ........ & \\
\hline echolsae, Cushmanidea.. & $\ldots \ldots \ldots$ \\
\hline Cytherideis........... & 4,7 \\
\hline edwardsi, Pseudocytheretta & 14 \\
\hline Electron micrographs ....... & 2,3 \\
\hline Eocytheropteron .......... & 9 \\
\hline \multicolumn{2}{|c|}{ yorktownensis $\ldots \ldots \ldots \ldots \ldots \ldots \ldots \ldots 4,9,20$} \\
\hline evax, Cythere ............. & 4,12 \\
\hline Echinocythereis ....... & 12 \\
\hline \multicolumn{2}{|c|}{ Henryhowella ............... 3, 4, 5, 12; pl. 4} \\
\hline Howella .............. & 12 \\
\hline oblongula, Cythere.... & 4,12 \\
\hline Trachyleberis .......... & 12 \\
\hline \multicolumn{2}{|c|}{ exanthemata, Actinocythereis ......... 4, 5, 11; pl. 3} \\
\hline Cythere ............... & 4,11 \\
\hline Trachyleberis ...... & 11 \\
\hline
\end{tabular}

F, G

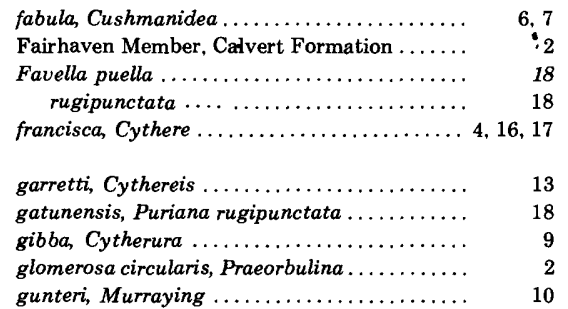

H

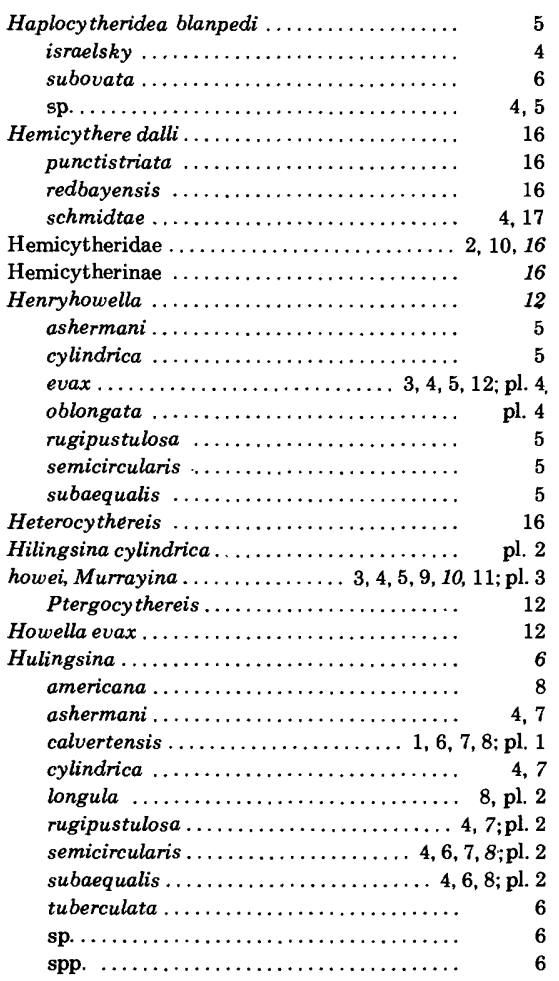

I, J, K

inaequivalvis, Cythere $\ldots \ldots \ldots \ldots \ldots \ldots \ldots . \ldots \ldots$ Cytheretta ....................... 16

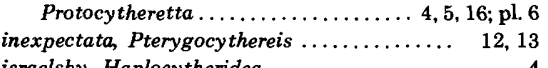

\begin{tabular}{l|}
2 \\
3 \\
4 \\
4 \\
7 \\
7 \\
4 \\
3 \\
9 \\
0 \\
2 \\
2 \\
4 \\
2 \\
2 \\
2 \\
3 \\
1 \\
1
\end{tabular}

James River, Va, Yorktown Formation ....... 3; pl. 4
Kirkwood Formation, N. J. ............... 11; pl. 3

\section{L}

latimarginata, Cythere

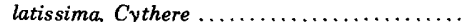

lectotypes

Leguminocythereis clarkana

whitei

(n...............

Leonardtown, Md., Choptank Formation ......

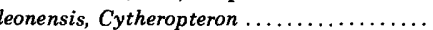

lienenklausi, Cythere....

Muellerina ................. 4, 5, 18, 19; pl. 7

Orionina.

Little Cove Point unit, St. Marys Formation.

longula, Cytherideis

Hulingsina $\ldots \ldots \ldots \ldots \ldots \ldots \ldots \ldots \ldots \ldots \ldots \ldots$
Lyons Creek $\ldots \ldots \ldots \ldots \ldots \ldots \ldots \ldots$

8; pl. 2

$$
\text { mar }
$$

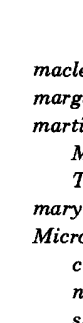

Neocaudites sp.

Neocy therideidae

18

nigrescens, Microcytherura

itidula, Cythere

calvertensis, $C y$ the

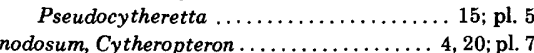

Paracytheridea

nomen dubium ........................ 12

nomenclature

o

oblongata, Henryhowella ................ pl. 4 oblongula, Cythere evax ................. 4, 12

ohmerti, Muellerina.

Orionina . . .

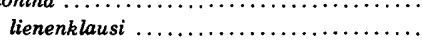

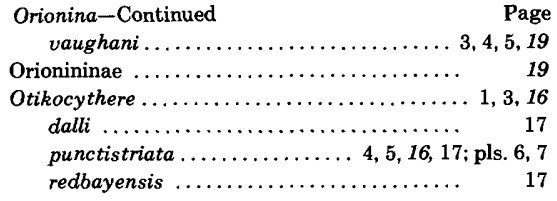

$\mathbf{P}$

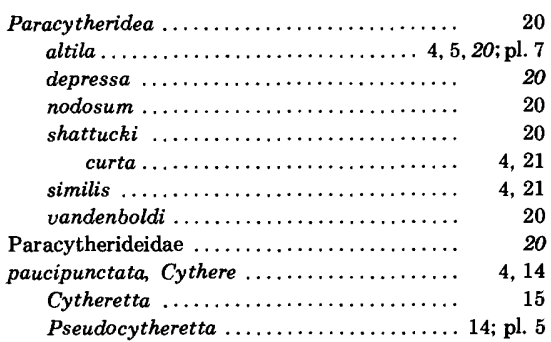
Pseudocytheretta .................. 14; pl. 5
aw Paw Point, Md., Choptank Formation .. 3, 5; pls. 1, 3 Peachblossom Creek, Md., Choptank Forma.

tion . . . . . . . . . . . . . 3, 15, 17; pls. 5, 6

Peratocytheridea $\ldots \ldots \ldots \ldots \ldots \ldots \ldots \ldots \ldots, 6$ bradyi ......................... 5 subovata .................... 2, 4,5,6;pl. 1 petricola, Aurila ........................ 16, 17 planibasalis, Buntonia .................. $\quad 14$ Cythere ....................... 4, 14 Echinocythereis .............4,5, 13, 14; pl. 4 plebeia, Bairdia ........................ 15 Cythere ......................... 4,15 (Bairdia)........................

Cytheretta ...................... $\quad 15$ Pseudocytheretta....... 4, 5, 14, 15, 16; pls. 5, 6 capax, Cythere ..................... 4,15 modica, Cythere .................. 4, 15

Plum Point, Md., Calvert Formation ........ 6,10

$12,16,18$; pls. $1,2,3,4,5$

fossil locality

Plum Point Marl Member, Calvert Formation.

Pontocythere ashermani .................. rugipustulosa (Hulingsina) ashermani (Hulingsina) rugipustulosa $\ldots \ldots \ldots \ldots \ldots$

porcella, Cythere. Pseudocytheretta.................... 15, 16; pl. 6 Praeorbulina glomerosa circularis ........... 2 Procedures...

producta, Cythere ..................... 4, 10

Protocytheretta ....................... 16 inaequivalvis .................. 4, 5, 16; pl. 6

Pseudocytheretta....................... 14 burnsi ............... 4, 5, 14, 15, 16; pls. 4, 5 calvertensis $\ldots \ldots \ldots \ldots \ldots \ldots \ldots \ldots \ldots \ldots, 15 ; \mathrm{pl} .5$ capax .............................. pl. 5 chesapeakensis ................... pl. 6 edwardsi .......................... 14 modica ...................... 15, 16; pl. 6

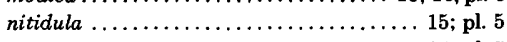
paucipunctata .................... 14; pl. 5 plebeia .............. 4, 5, 14, 15, 16; pls. 5, 6 porcella ......................... 15, 16; pl. 6 toumeyi ...................... 15; pl. 5 ulrichi $\ldots \ldots \ldots \ldots \ldots \ldots \ldots \ldots \ldots \ldots, \quad 15$ sp. ............................ 14 Pterygocythereidini $\ldots \ldots \ldots \ldots \ldots \ldots \ldots \ldots \ldots, 12$ Pterygocythereis ....................... 12 americana ................... 4,5,12; pl. 4 cormuta americana ................... 12

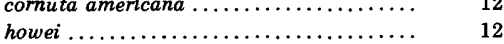

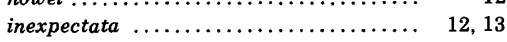
puella, Favella...................... $\quad 18$ punctistriata, Cythere .................. 1, 3, 4, 16 Hemicythere $\ldots \ldots \ldots \ldots \ldots \ldots \ldots \ldots \ldots, \ldots, 16$ Otikocythere $\ldots \ldots \ldots \ldots \ldots \ldots \ldots, 5,16,17 ;$ pls. 6,7

Puriana ............................ 18 rugipunctata $\ldots \ldots \ldots \ldots \ldots \ldots \ldots \ldots \ldots, 3,4,5,18$ gatunensis .................. 18 
$\mathbf{R}$

\begin{abstract}
Page
\end{abstract}

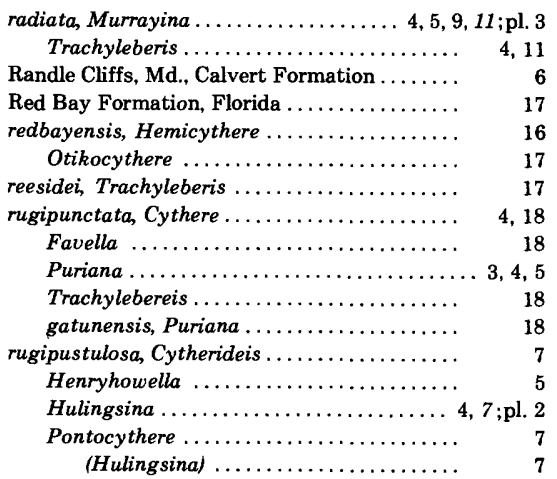

S

St. Leonard Member, Choptank Formation .... 2

St. Marys Formation ...................... 1, 2,9

Unit A $\ldots \ldots \ldots \ldots \ldots \ldots \ldots \ldots \ldots \ldots, \quad 6,15$

Unit B $\ldots \ldots \ldots \ldots \ldots \ldots \ldots \ldots \ldots \ldots, 6,13,15$

Unit C $\ldots \ldots \ldots \ldots \ldots \ldots$

schmidtae, Hemicythere................. 4,17

Thaerocythere .............. 4, 5, 17, 18; pl. 7

Scientist's Cliffs, Md., Choptank Formation ... 20

semicircularis ....................... 8

Cytherideis ......................... 4,8

Henryhowella .................. 5

Hulingsina ................ 4, 6, 7, 8; pl. 2

setipunctata, Cytheridea ............... 6

Shattucki, Cythere .................... 4, 9, 20

Microcytherura ............. 4, 5, 20, 21; pl. 7

Paracy theridea

20,21

Shattuckocythere ................... 20,21

curta, Paracytheridea

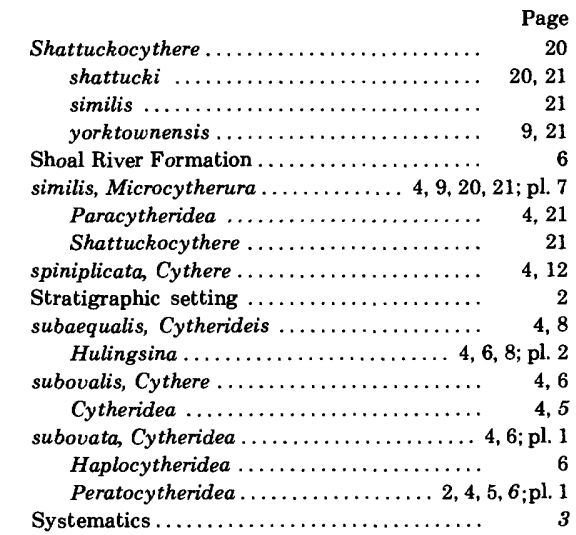

\section{$\mathrm{T}$}

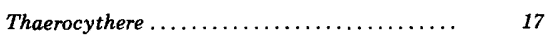
crenulata.......................... 17 schmidtae $\ldots \ldots \ldots \ldots \ldots \ldots \ldots \ldots 4,5,17,18 ;$ pl. 7

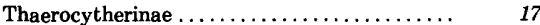

Thaerocytherini $\ldots \ldots \ldots \ldots \ldots \ldots \ldots \ldots \ldots, \quad 17$

toumeyi, Cythere ...................... 4,14

Pseudocytheretta .................. 15; pl. 5

Trachyleberididae

Trachyleberidinae $\ldots \ldots \ldots \ldots \ldots \ldots \ldots \ldots \ldots, \quad g$

Trachyleberidini .

Trachyleberis clarkana .................. 13,14

evax .......................... 12

exanthemata ..................... 11

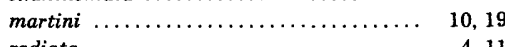

radiata....................

reesidei $\ldots \ldots \ldots \ldots \ldots \ldots \ldots \ldots \ldots \ldots, 17$

$\begin{array}{ll}\text { rugipunctata } \ldots \ldots \ldots \ldots \ldots \ldots \ldots \ldots \ldots \ldots & 18 \\ \text { vaughani } \ldots \ldots \ldots \ldots \ldots \ldots \ldots \ldots \ldots \ldots & 19\end{array}$ tuberculata, Hulingsina ............... $\quad \begin{array}{r}\text { Page } \\ 6\end{array}$

U, V

ulrichi, Cytheretta .................... 15

Pseudocytheretta .................... 15

Unit A, Little Cove Point unit, St. Marys Formation $\ldots \ldots \ldots \ldots \ldots \ldots \ldots, 2,6,15$

Unit B, St. Marys Formation .......... 2, 6, 9, 13, 15

Unit C, Claremont Manor Member, Eastover Formation $\ldots \ldots \ldots \ldots 2,7,13,17,18,20$

Unit D, Cobham Bay Member, Eastover Formation ............ 2, 3, 7, 13, 17, 18, 20

vandenboldi, Paracytheridea .............. $\quad 20$ vaughani, Cythere $\ldots \ldots \ldots \ldots \ldots \ldots \ldots \ldots \ldots \quad 4,19$ Orionina ..................... 3, 4, 5, 19

Trachyleberis ..................... 19

Virginia St. Marys ..................... 2

virginiensis, Clithrocytheridea .............

Cytheridea ................... 3,4,5; pl. 1

W, Y, Z

whitei, Leguminocythereis ...............

19

Yorktown Formation .... 1, 2, 5, 7, 9, 12, 15, 20; pls. 1, 2 yorktownensis, Cytheropteron ......... 4, 5, 9; pl. 2

Eocytheropteron .................. 4, 9, 20

Shattuckocythere ................. 9, 21

Zones 1-15, Calvert Formation ............ 2

Zones 16-20, Choptank Formation ........... 2

Zones 21-24, St. Marys Formation .......... 


\section{PLATES 1-7}

Contact photographs of the plates in this report are available, at cost, from the U.S. Geological Survey Photographic Library, Federal Center, Denver, Colorado 80225. 


\section{PLATE 1}

FIGURES 1, 8. Cytheridea subovalis (Ulrich and Bassler, 1904).

1. Lateral view, left valve, female; Plum Point, Md., Calvert Formation. USNM $256021 . \times 95$.

8. Lateral view, Left valve, female, Ulrich and Bassler's Paw Paw Point, Md., Choptank Formation. USNM 35439. $\times 105$. Holotype.

2, 5. Hulingsina calvertensis new species.

2. Lateral view, left valve, female; $0.8 \mathrm{~km}$ north of Randle Cliffs Beach, North Beach $71 / 2$-minute quadrangle, Maryland; Calvert Formation. USNM 256022. $\times 100$. Holotype.

5. Lateral view, left valve, female, Plum Point, Md., Calvert Formation. USNM 35446. $\times 120$.

3, 6. Cytheridea diagonalis (Malkin, 1953).

3. Lateral view, right valve, male; Malkin locality 13-3, Calvert Formation. USNM 256019. $\times 100$. Paralectotype.

6. Lateral view, right valve, female; Malkin locality 13-3, Calvert Formation. USNM 256018. $\times 100$. Lectotype. 4. Peratocytheridea subovata (Ulrich and Bassler, 1904).

Left valve, male; Plum Point, Calvert Formation. USNM 648513. $\times 90$. Paralectotype.

7. Cytheridea virginiensis (Malkin, 1953).

Lateral view, left valve, female; Malkin locality VA-10, Yorktown Formation. USNM 256020. $\times 125$. Lectotype. 


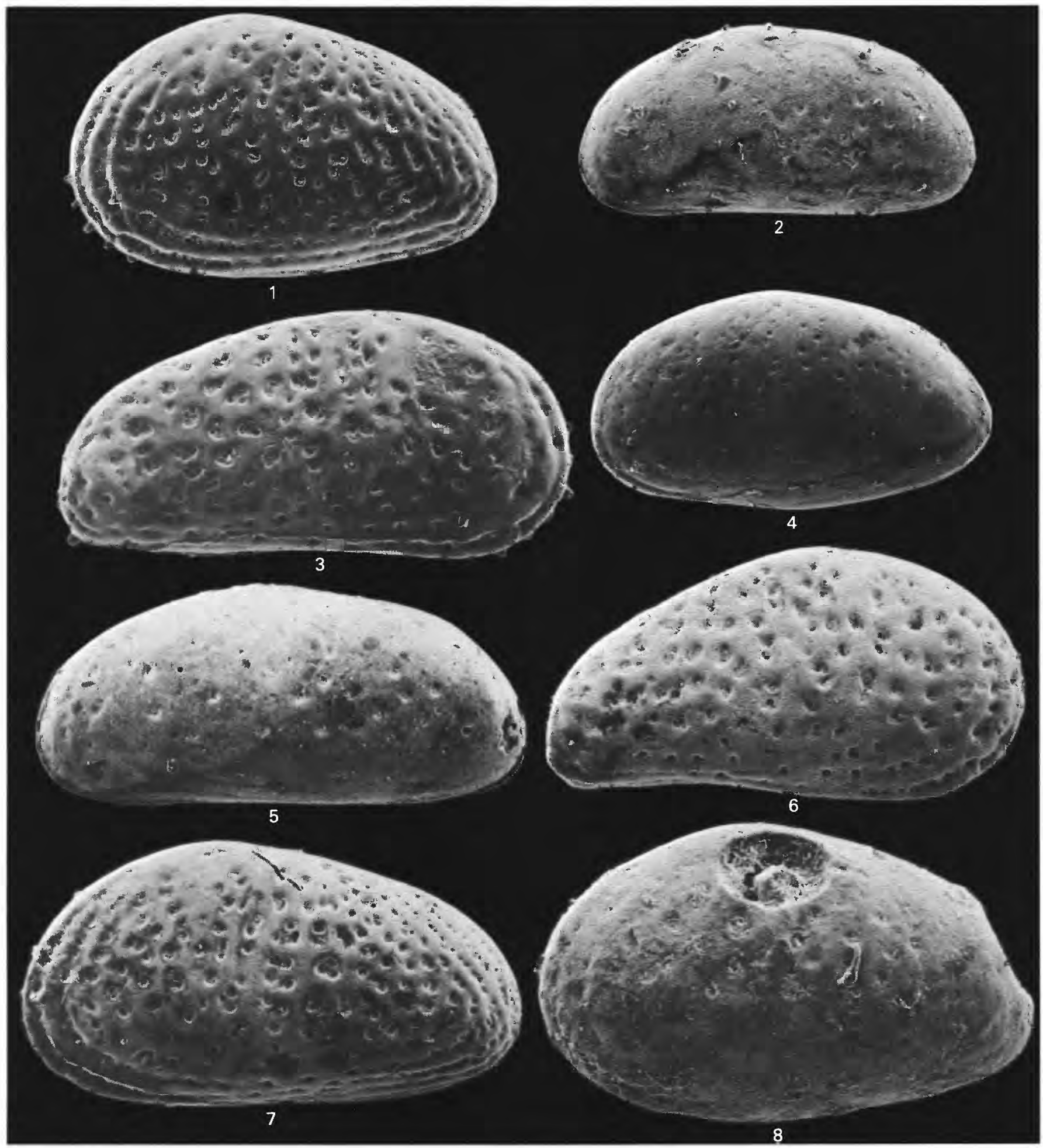

CYTHERIDEA, HULINGSINA, AND PERATOCYTHERIDEA 


\section{PLATE 2}

Figure 1. Hulingsina rugipustulosa (Edwards, 1944).

Lateral view, right valve, male; Malkin locality VA-12, Yorktown Formation. USNM 256023. (Lectotype of $H$. echolsae (Malkin, 1953)). $\times 150$.

2. Hulingsina cylindrica (Ulrich and Bassler, 1904).

Lateral view, left valve, male (?); Ulrich and Bassler's Plum Point locality, Calvert Formation. USNM $35447 . \times 110$. Holotype.

3-5. Hulingsina semicircularis (Ulrich and Bassler, 1904).

3. Lateral view, right valve, male; Ulrich and Bassler's Plum Point locality, Calvert Formation. USNM 35448 a. $(=$ lectotype of $H$. longula (Ulrich and Bassler, 1904)). $\times 100$.

4. Lateral view, left valve, male; Ulrich and Bassler's Plum Point locality, Calvert Formation. USNM 35448 b. $(=$ paralectotype of $H$. longula (Ulrich and Bassler, 1904)). $\times 110$.

5. Lateral view, right valve, female; Ulrich and Bassler's Plum Point locality, Calvert Formation. USNM 35449 a. $\times 120$. Lectotype.

6. Hulingsina subaequalis (Ulrich and Bassler, 1904).

Lateral view, female; Ulrich and Bassler's Plum Point locality, Calvert Formation. USNM 35450. $\times 110$. Holotype. 7. Cytheropteron? yorktownensis (Malkin, 1953).

Lateral view, left valve, female; Malkin locality VA-4, Yorktown Formation. USNM 256025. × 250. Lectotype.

8. Cytherura coryelli Malkin, 1953.

Lateral view, left valve, female; Malkin locality 14-5, Choptank Formation. USNM 256024. × 200. Lectotype. 


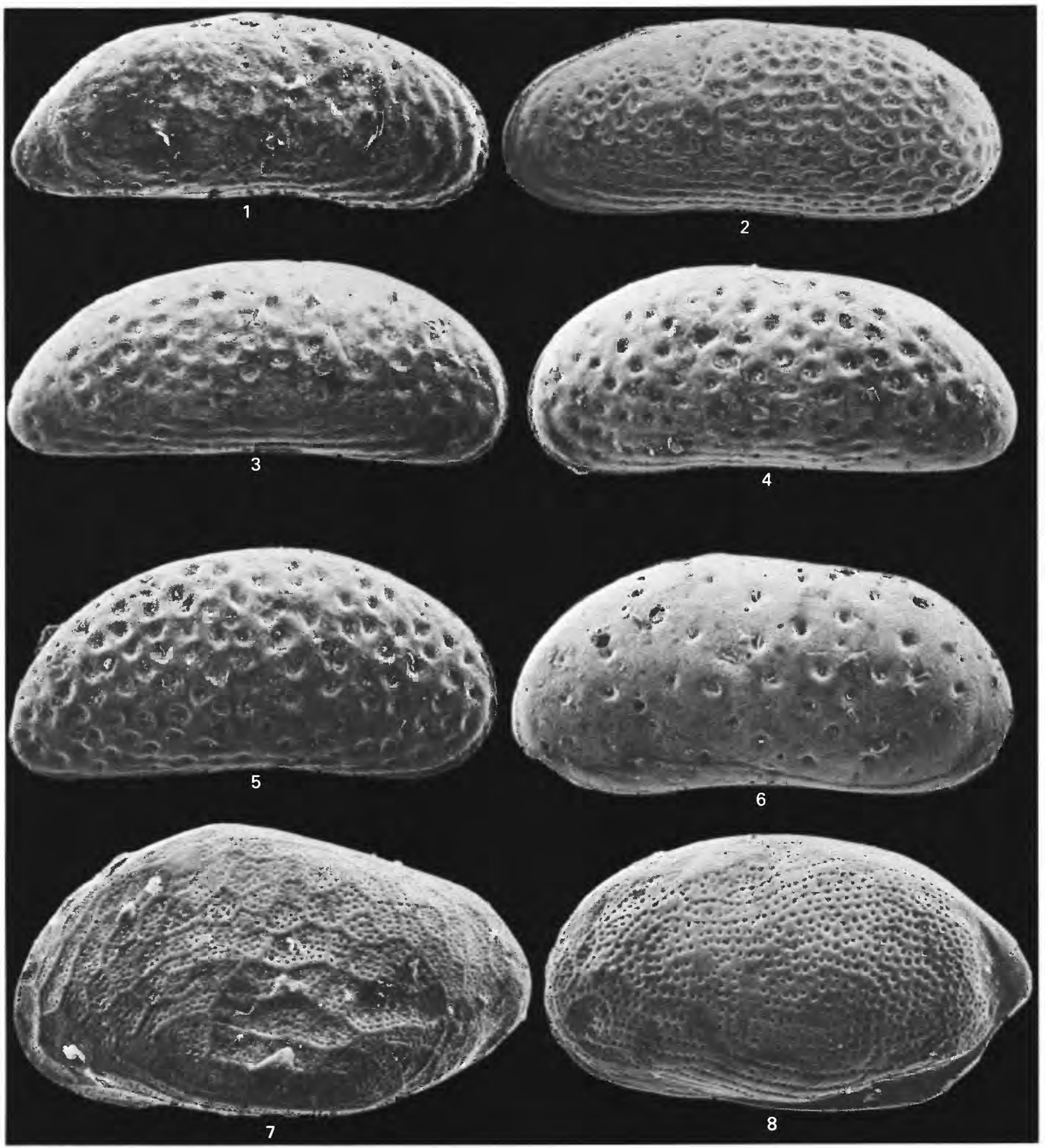

HULINGSINA, CYTHEROPTERON, AND CYTHERURA 


\section{PLATE 3}

Figure 1. Murrayina radiata (Malkin, 1953).

Lateral view, right valve, female; Malkin locality NJ-9, Kirkwood Formation. USNM 256026. × 110. Lectotype.

2, 4. Murrayina martini (Ulrich and Bassler, 1904).

2. Lateral view, right valve, male; Plum Point, Md., Calvert Formation. USNM 35423 a. $\times 110$. Lectotype.

4. Lateral view, left valve, female; Plum Point, Calvert Formation. USNM 35423 b. $\times 120$. Paralectotype.

3, 5. Murrayina howei (Ulrich and Bassler, 1904).

3. Lateral view, right valve, male; Plum Point, Calvert Formation. USNM 35433 a. $\times 100$. Lectotype.

5. (Holotype of M. dorsicornis (Ulrich and Bassler, 1904)). Lateral view, left valve, juvenile; Plum Point, Calvert Formation. USNM $35415 . \times 145$.

6. Murrayina martini? (Ulrich and Bassler, 1904).

(= holotype of $M$. dorsicornis bicornis (Ulrich and Bassler, 1904)). Lateral view, left valve, juvenile; Ulrich and Bassler's Paw Paw Point, Md., Choptank Formation. USNM 35416. $\times 210$.

7, 8. Actinocythereis exanthemata (Ulrich and Bassler, 1904).

7. Lateral view, right valve, female; Plum Point, Calvert Formation. USNM 35419 b. $\times 120$. Paralectotype.

8. Lateral view, right valve, female; Plum Point, Calvert Formation. USNM 35419 a. $\times 110$. Lectotype. 


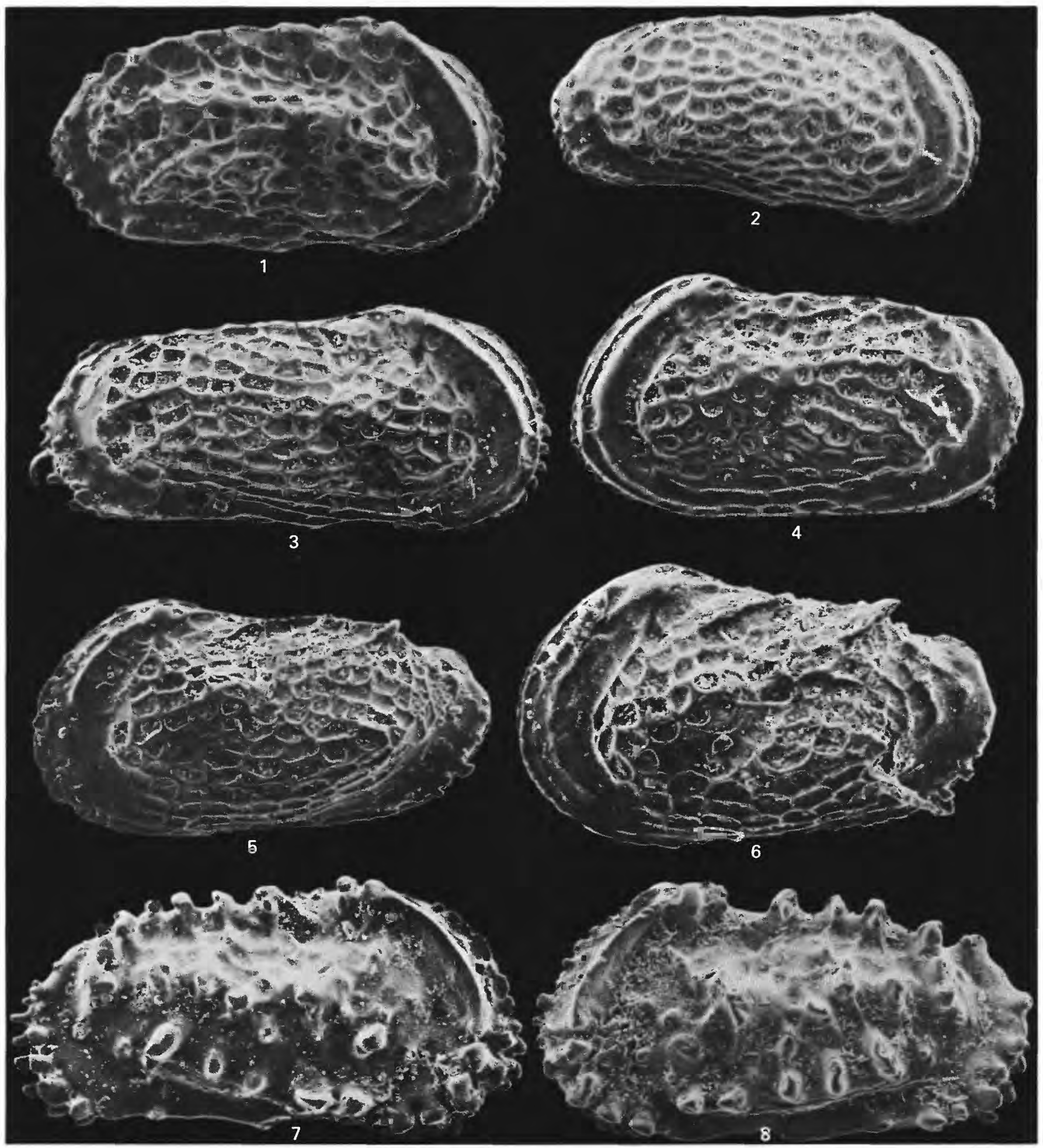

MURRAYINA AND ACTINOCYTHEREIS 


\section{PLATE 4}

FiguRES 1, 2. Henryhowella evax (Ulrich and Bassler, 1904).

1. Lateral view, left valve, male $(H$. oblongata); Plum Point, Md., Calvert Formation. USNM 35418 a. $\times 100$. Lectotype.

2. Lateral view, left valve, female; Plum Point, Calvert Formation. USNM 35417 a. $\times 110$. Lectotype.

3. Actinocythereis alaris (Ulrich and Bassler, 1904).

Lateral view, left valve, juvenile; James River, Va., Yorktown Formation. USNM 35451. $\times 120$. Holotype.

4. Pterygocythereis americana (Ulrich and Bassler, 1904).

Lateral view, left valve, female; Plum Point, Calvert Formation. USNM 35452 a. $\times 95$. Lectotype.

5. Echinocythereis clarkana (Ulrich and Bassler, 1904).

Lateral view, left valve, male; Plum Point, Calvert Formation. USNM 35413 a. $\times 80$. Lectotype.

6. Pseudocytheretta burnsi (Ulrich and Bassler, 1904).

Lateral view, left valve, male; Plum Point, Calvert Formation. USNM 35411 a. $\times 90$. Lectotype.

7. Echinocythereis planibasalis (Ulrich and Bassler, 1904).

Lateral view, right valve, male; James River, Yorktown Formation. USNM 35428. $\times 95$. Holotype. 8. Echinocythereis miniscula (Ulrich and Bassler, 1904).

Lateral view, left valve, female; Plum Point, Calvert Formation. USNM 35414 a. $\times 100$. Lectotype. 


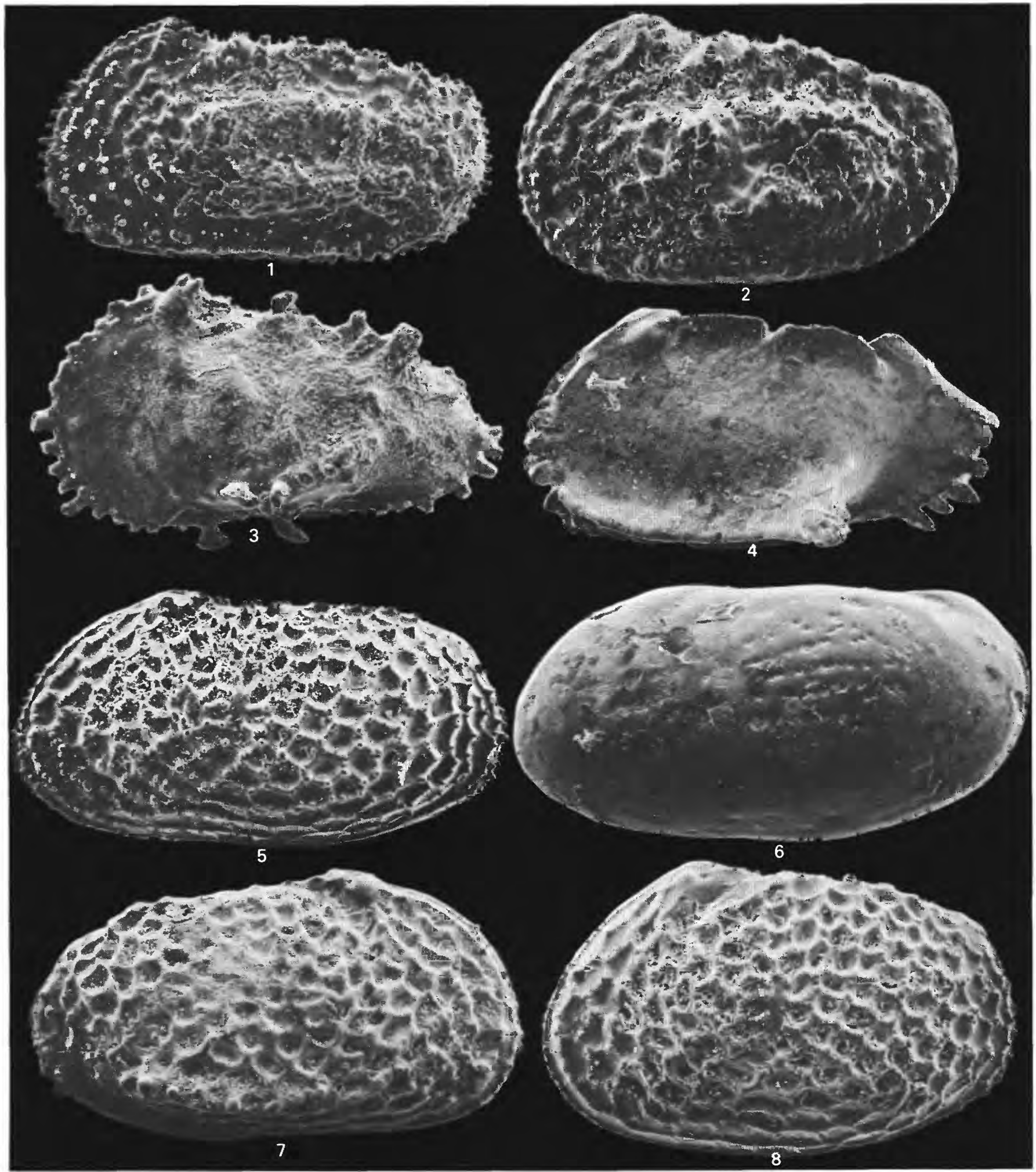

HENRYHOWELLA, ACTINOCYTHEREIS, PTERYGOCYTHEREIS, ECHINOCYTHEREIS, AND PSEUDOCYTHERETTA 


\section{PLATE 5}

Figures 1, 4, 5. Pseudocytheretta plebeia (Ulrich and Bassler, 1904).

1. Lateral view, right valve, female; Plum Point, Md., Calvert Formation. USNM 256028. $\times 80$.

4. Lateral view, left valve, female; Plum Point, Calvert Formation. USNM 35429 a. $\times 85$. Lectotype.

5. Lateral view, right valve, female (lectotype of $P$. capax (Ulrich and Bassler, 1904)); Calvert Formation. USNM 35430 a. $\times 85$.

2, 3, 6, 7, 8. Pseudocytheretta burnsi (Ulrich and Bassler, 1904).

2. Lateral view, left valve, juvenile (lectotype of $P$. nitidula (Ulrich and Bassler, 1904)), Plum Point, Calvert Formation. USNM 35425 a. $\times 105$

3. Lateral view, right valve, female, Bed $10,0.8 \mathrm{~km}$ north of Plum Point, Calvert Formation. USNM 256027. $\times 80$.

6. (Holotype of $P$. paucipunctata (Ulrich and Bassler, 1904)). Lateral view, left valve, female; $4.8 \mathrm{~km}$ southwest of Easton, Md., Choptank Formation. USNM 35427. $\times 85$.

7. (Lectotype of $P$. toumeyi (Ulrich and Bassler, 1904)). Lateral view, right valve, juvenile; Peachblossom Creek, Trappe 71/2-minute quadrangle, Maryland; Choptank Formation. USNM 35440. $\times 160$.

8. (Lectotype of $P$. calvertensis (Ulrich and Bassler, 1904)). Lateral view, left valve, juvenile; Plum Point, Calvert Formation. USNM $35426 \mathrm{a} . \times 120$. 


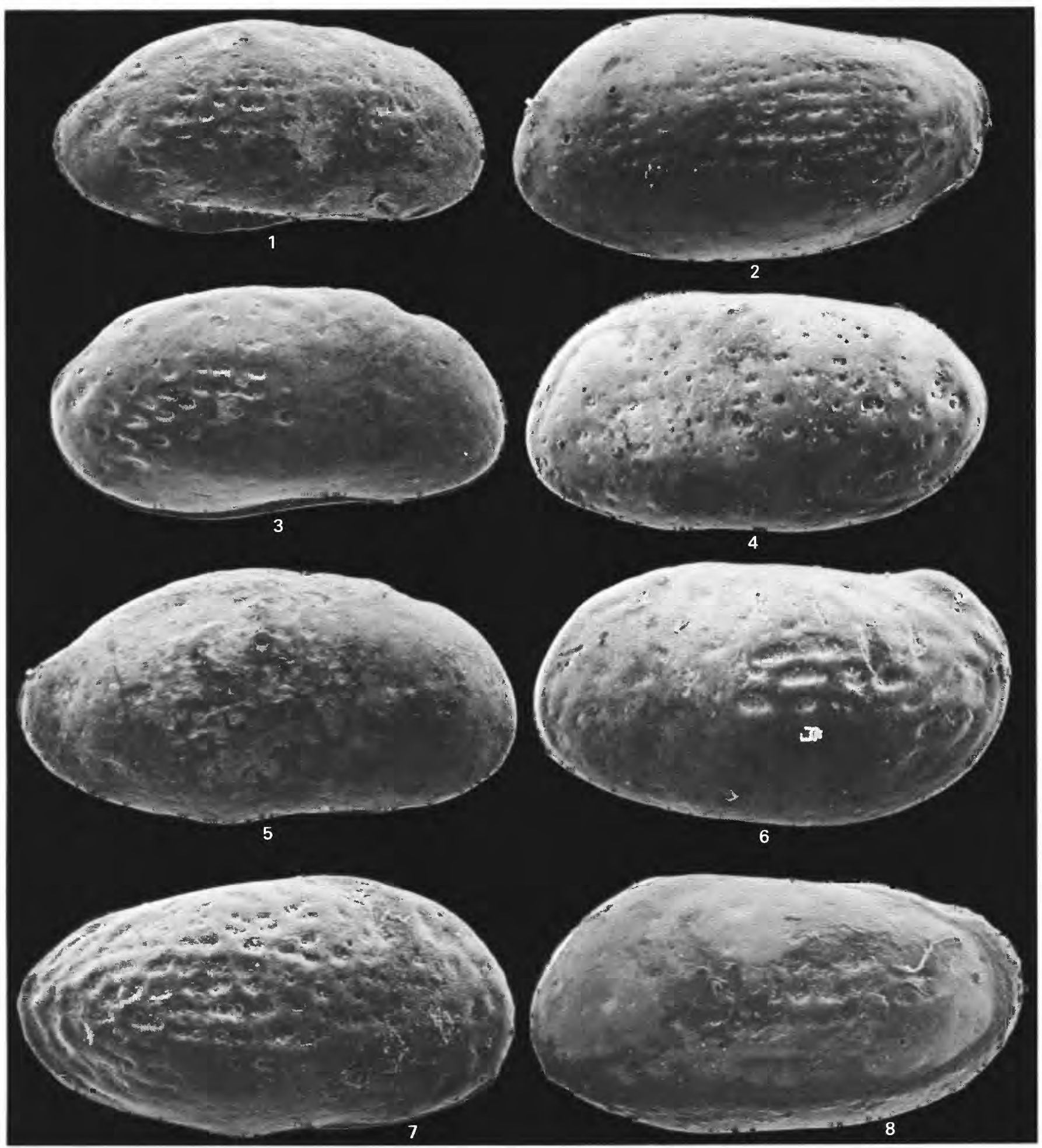

PSEUDOCYTHERETTA 


\section{PLATE 6}

Figures 1-4. Otikocythere punctistriata (Ulrich and Bassler, 1904). New genus

1. Lateral view, left valve, interior, female; Peachblossom Creek, Md., Choptank Formation. USNM 256029. $\times 135$.

2. Lateral view, right valve, interior, female; Peachblossom Creek, Choptank Formation. USNM 256030. × 135 .

3. Lateral view, left valve, female; Church Hill, Md., Calvert Formation. USNM 35435. $\times 155$. Paratype.

4. Lateral view, left valve, female; Peachblossom Creek, Choptank Formation. USNM 256031. × 160 .

5-7. Pseudocytheretta plebeia (Ulrich and Bassler, 1904).

5. (Lectotype of $P$. modica (Ulrich and Bassler, 1904)). Lateral view, left valve, female; Plum Point, Md., Calvert Formation. USNM 35431 a. $\times 100$.

6. (Lectotype of $P$. porcella (Ulrich and Bassler, 1904)). Lateral view, left valve, juvenile; Plum Point, Calvert Formation. USNM 35432 a. $\times 130$.

7. (Holotype of $P$. chesapeakensis (Ulrich and Bassler, 1904)). Lateral view, right valve, juvenile; Plum Point, Calvert Formation. USNM 35444. $\times 130$.

8. Protocytheretta inaequivalvis (Ulrich and Bassler, 1904).

Lateral view, right valve; Plum Point, Calvert Formation. USNM 35421 a. $\times 85$. Lectotype. 


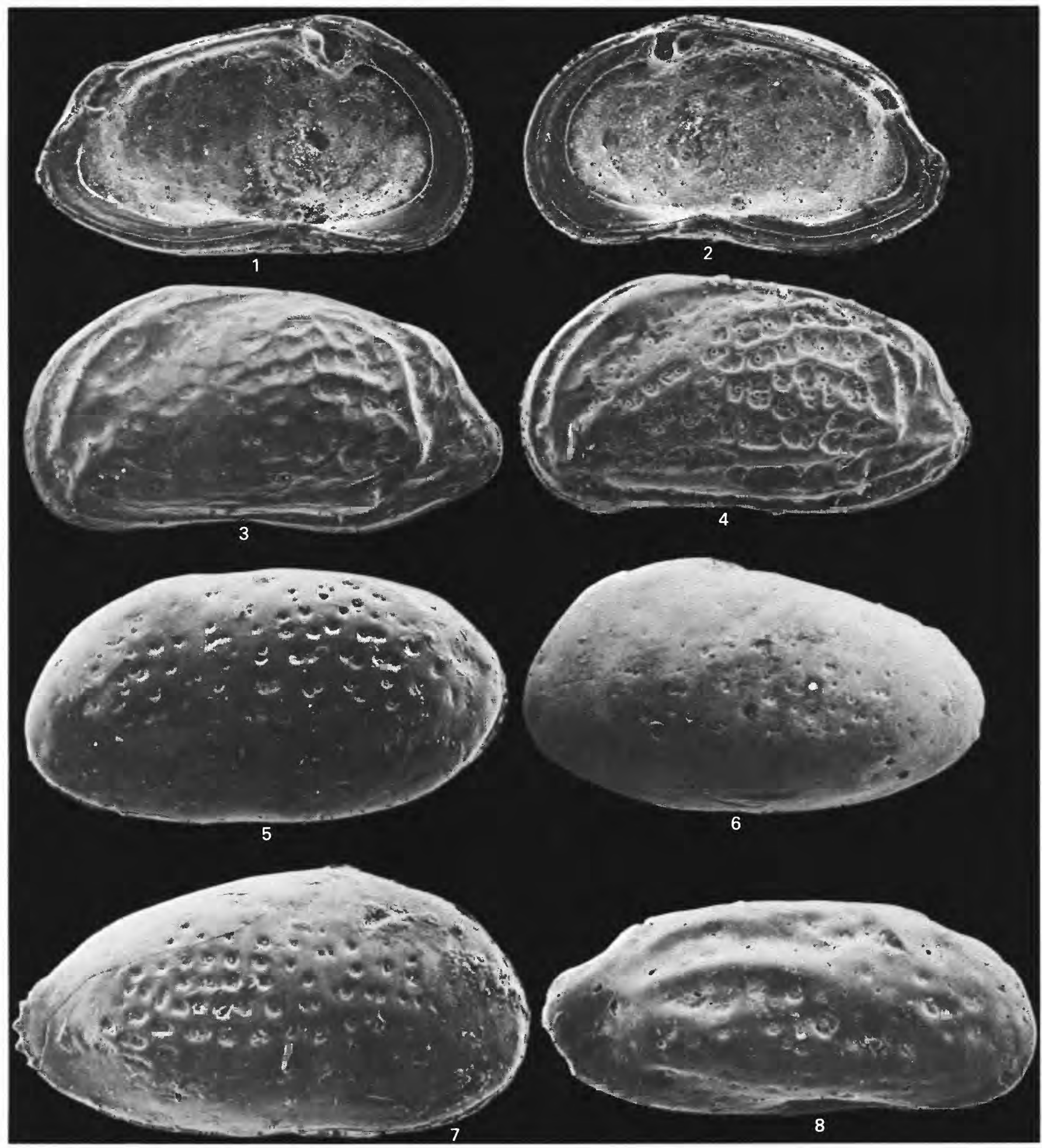

OTIKOCYTHERE, PSEUDOCYTHERETTA, AND PROTOCYTHERETTA 


\section{PLATE 7}

FigurE 1. Microcytherura shattucki (Ulrich and Bassler, 1904).

Lateral view, left valve, female, Bed 17, Scientists Cliffs, Md., Choptank Formation. USNM 256036. $\times 135$.

2, 3. Muellerina micula (Ulrich and Bassler, 1904).

2. Lateral view, left valve, female, Calvert Formation. USNM 256035. $\times 125$.

3. Lateral view, left valve, Juvenile, Plum Point, Md., Calvert Formation. USNM 35424 a. $\times 180$. Lectotype.

4. Muellerina lienenklausi (Ulrich and Bassler, 1904).

Lateral view, left valve, female, Plum Point, Calvert Formation. USNM 256034. × 120.

5. Otikocythere punctistriata (Ulrich and Bassler, 1904).

Lateral view, left valve, juvenile, Peachblossom Creek, Md., Choptank Formation. USNM 256032. × 160 .

6. Bensonocythere calverti (Ulrich and Bassler, 1904).

Lateral view, left valve. Plum Point, Calvert Formation. USNM 35412. × 115. Holotype.

7. Paracytheridea altila Edwards, 1944.

(= holotype of Cytheropteron nodosum Ulrich and Bassler, 1904). Lateral view, right valve, James River, Va., Yorktown Formation. USNM 35443. $\times 145$.

8. Thaerocythere schmidtae (Malkin, 1953).

Lateral view, left valve, female, Malkin (1953) locality VA-9, Yorktown Formation. USNM 256033. × 130. Lectotype.

9. Microcytherura similis (Malkin, 1953).

Lateral view, left valve, female, Malkin (1953) locality VA-10, Yorktown Formation. USNM 256038. $\times 170$. Lectotype. 10. Microcytherura curta (Malkin, 1953).

Lateral view, left valve, female, Malkin (1953) locality VA-10, Yorktown Formation. USNM 256037. × 160. Lectotype. 


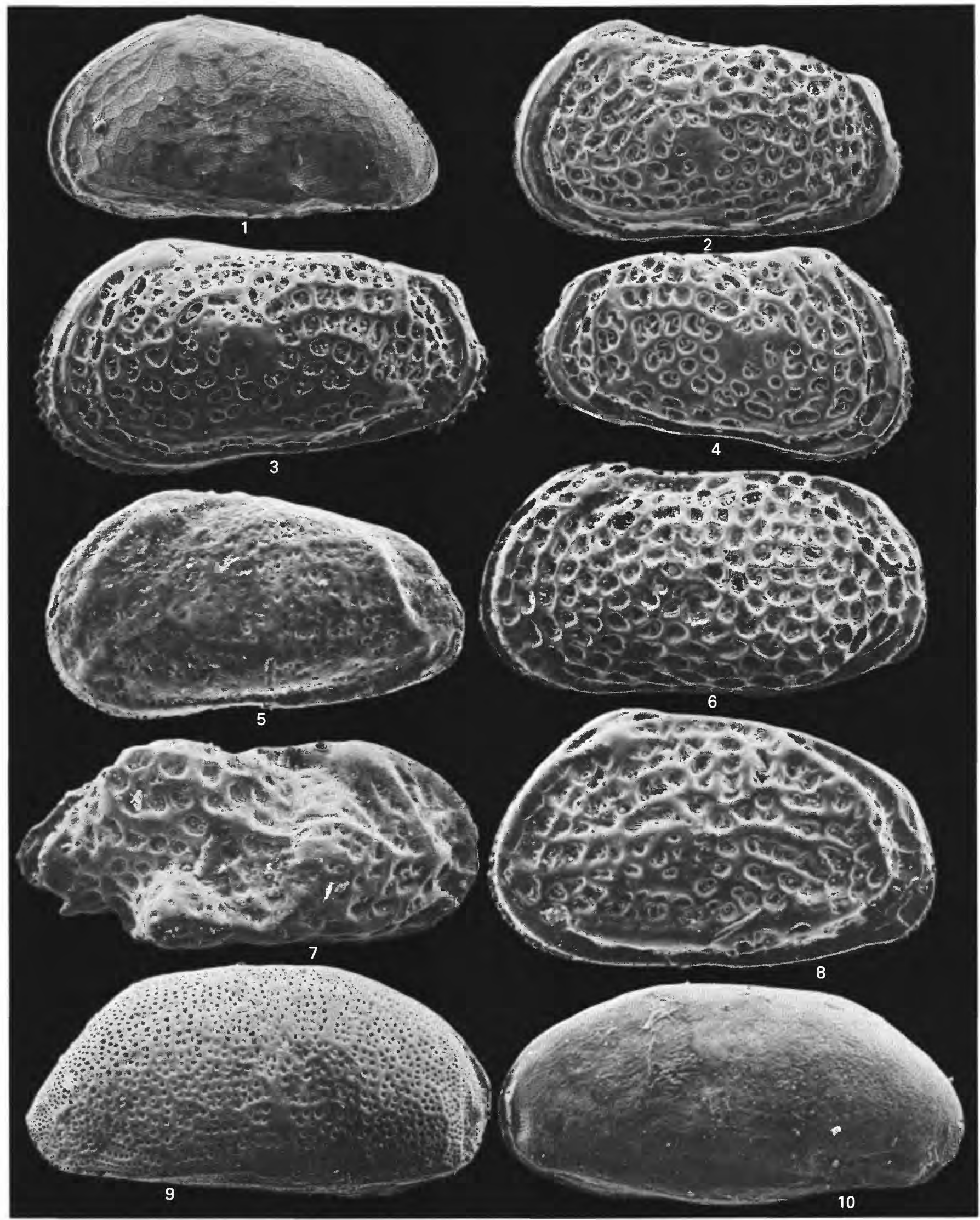

MICROCYTHERURA, MUELLERINA, OTIKOCYTHERE, BENSONOCYTHERE, PARACYTHERIDEA, AND THAEROCYTHERE 